\title{
Identification and Analysis of Ceramics Context on the Basis of Remainings of Burial Environment (Samples of Grey Ceramics Related to Iron Age)
}

\author{
M. B. KASIRI ${ }^{\mathrm{a}^{*}}$, H. GHORBANI ${ }^{\mathrm{b}}$ and Y., NAZARIEH ${ }^{\mathrm{c}}$ \\ ${ }^{a}$ Assistant professor, Research center on restoration of historical monuments, Tabriz Islamic Art University, \\ Tabriz, IRAN \\ ${ }^{\mathrm{b}}$ Assistant professor, Faculty of Arts, Birjand University, Birjand, IRAN \\ ${ }^{c}$ M.Sc. in Archaeometry, Faculty of Applied Arts, Tabriz Islamic Art University, Tabriz, IRAN
}

\begin{abstract}
Context of the archaeological findings is an important part of these artifacts and many useful information, regarding the provenance, application and dating of findings must be determined considering the characteristic of corresponding context. In some cases, the context of an historical objects is missing and hence, the accuracy of the information regarding the historical object is unsatisfactory. However, some types of laboratory experiments are able to provide the required information regarding the archaeological context of the object. In this study, it was tried to find the context of five gray Iron Age pottery pieces belong to the Museum of Ancient Iran. In order to identify and measure the elements in sediments and body of the samples, inductively coupled plasmaoptical emission spectroscopy (ICP-OES) technique was used. Also, to identify the anions present in sediments on the samples, ion chromatography (IC) technique was employed. The results showed that, the sample MB-1 and MB-2, on the basis of elements present, have the same context, where the specifications are very close to the cemetery. Also, based on the high concentrations of calcium carbonate deposits in the chemical composition of MB-3, this sample could be related to the kitchen or floor of a residential area. Regarding the samples termed MB-4 and MB-5, as the results of elemental analysis showed the presence of some elements such as potassium, magnesium, iron, and titanium and, a positive correlation of these elements with each other, as well as a negative correlation between potassium and magnesium with $\mathrm{Si}$, the context ought to be associated with fire, such as oven and grill found in the kitchen. Results of polarized light microscopy (PM) also showed a close correlation and structural similarity based on the type of tempering with gray earthenware tempering, traditionally used during the Iron Age, which are clay minerals having relatively smooth and homogeneous texture in all the samples.
\end{abstract}

Keywords: Context, Grey earthenware, Iron age, ICP-OES, Ion chromatography, Petrography

* _ Corresponding author: m.kasiri@tabriziau.ac.ir 


\section{شناسايى و تحليل بستر آثار سفالى بر مبناى بقاياى محيط دفن

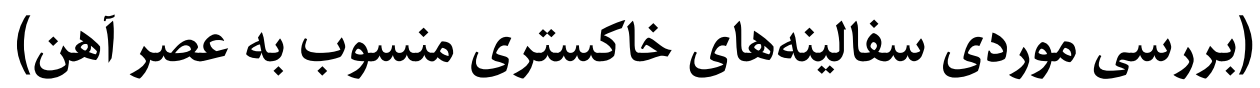 \\ مسعود باقرز اده كثيرى '"؛ حميدرضا قربانى '؛ ياسر نظريه \\ ' استاديار و عضو مركز تحقيقات مرمت بنا و بافتهاى تاريخى دانشعاه هنر اسلامى تبريز، تبريز، ايران

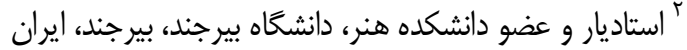

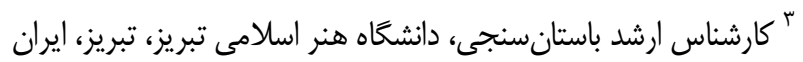

جكيده

در ثروهش حاضر سعى شده است تا بلوسيلهى مطالعات آزمايشخاهى بستر و محيط دفن احتمالى ينج نمونه سفال خاكسترى عصر

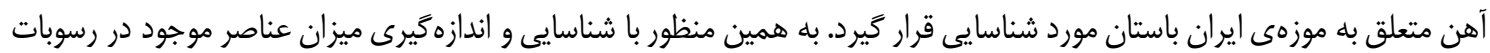

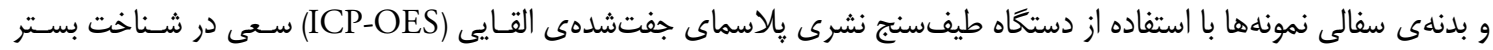

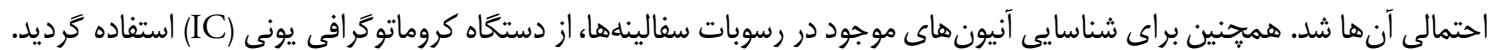

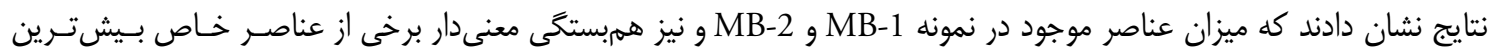

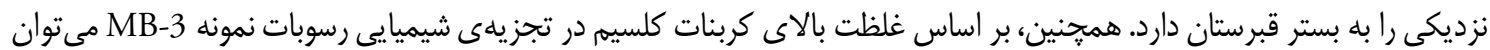

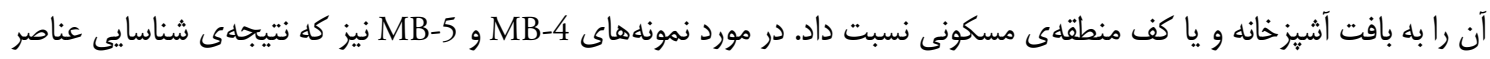

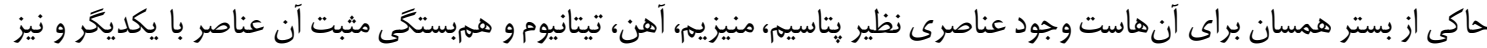

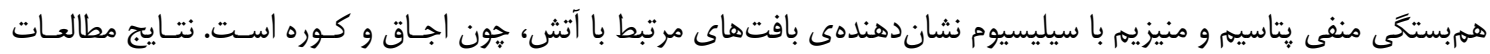

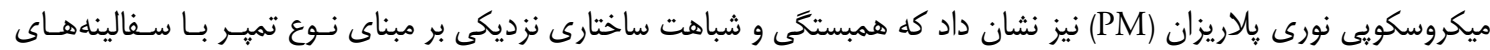

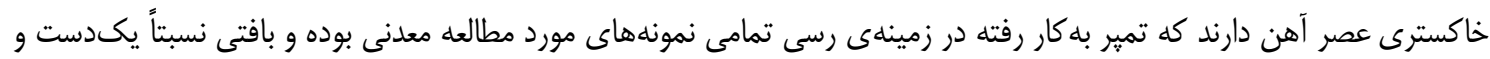
همخن دارند. وازَّان كليدى: بستر، سفال خاكسترى، عصر آهن، يلاسماى جفت شده القايى ICP-OES، كروماتوكرافى يونى IC، يتروگرافى 


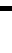

تغييرات طبيعى، تغييرات فرهنكى يا به ويزه حفارىهاى

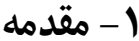

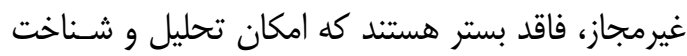

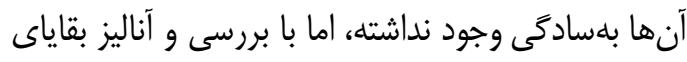

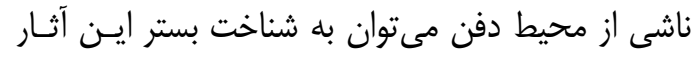

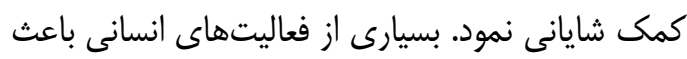

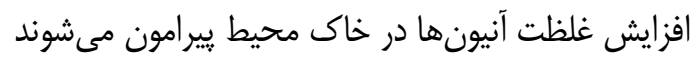

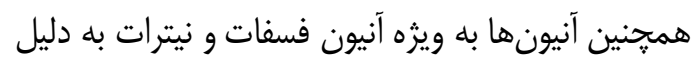

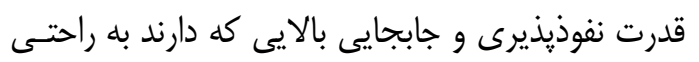
در اثر حضور رطوبت در بدنههاى سراميكى نفوذ مى كنند

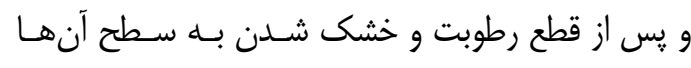

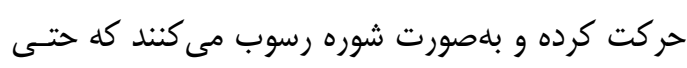

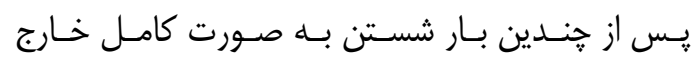
نمىشوند (May and Jones, 2006). بنابر اين تجزيـهـ

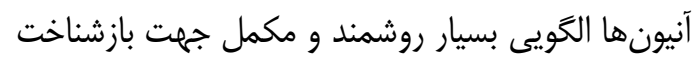

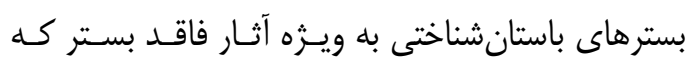

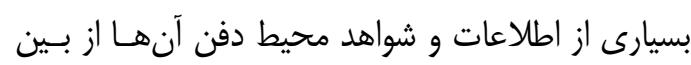
رفتهاند ارائه مىنمايد. غلظت آنيونها به ويثه آنيون فسفات كاربرد بسـيار

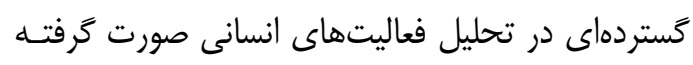

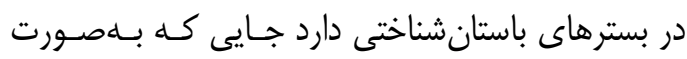
طبيعى، فعاليتهاى انسانى باعث افزايش فسفات خـاك داري

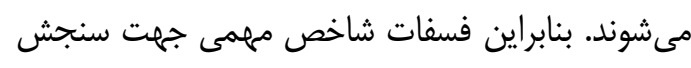

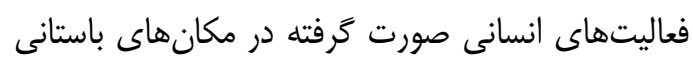

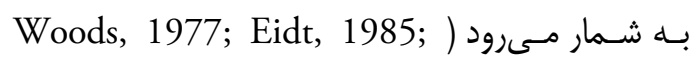
- (Dunning, 1993

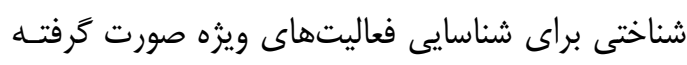

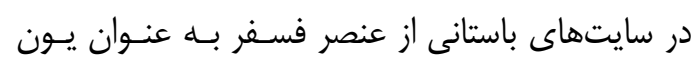

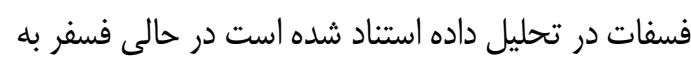
صورت عنصرى تـى اتمسى و در بسـيارى از تركيبـات

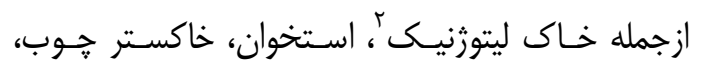

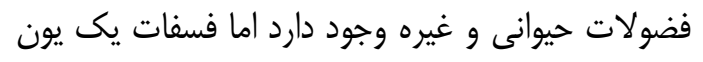

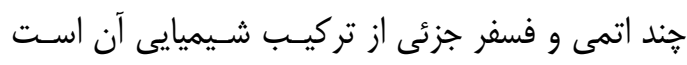

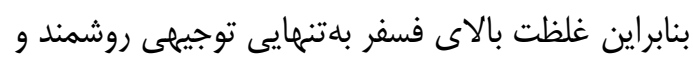
علمى براى تحليل فعاليتهاى انسانى ويزه در يك بلى بستر

باستانشناختى، مرتبط با يون فسفات نيست فيتاليت

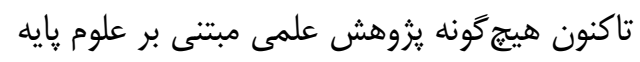

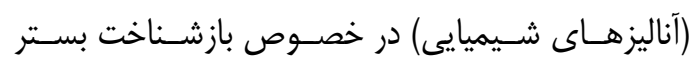

توليد سفال خاكسترى رنغ كه يكى از شاخصـهــاى

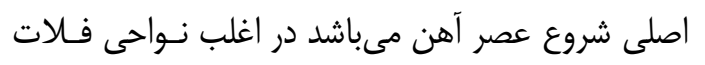

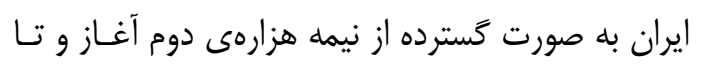

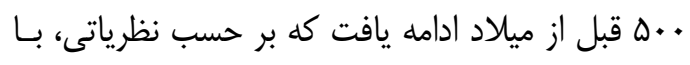

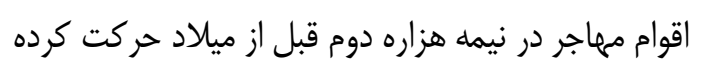

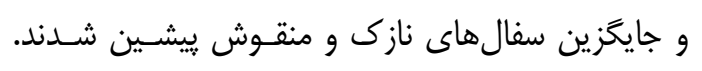

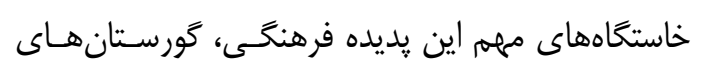

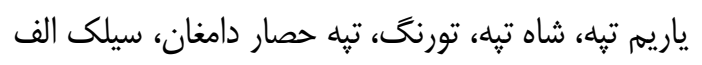

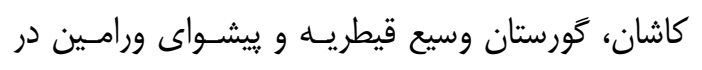

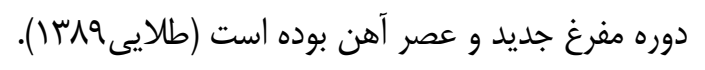

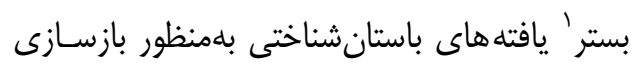

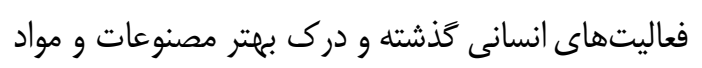

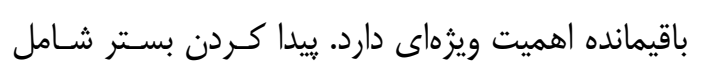

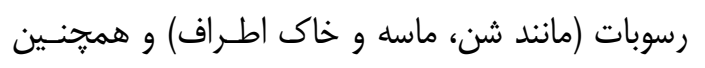

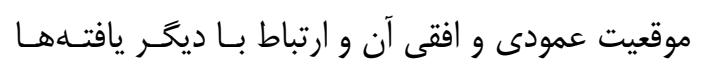

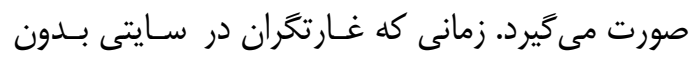

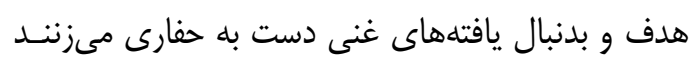

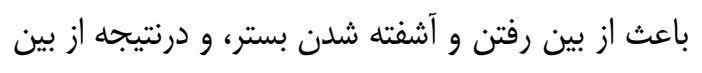

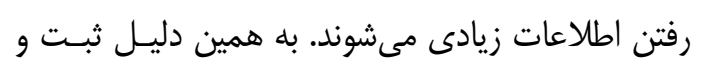

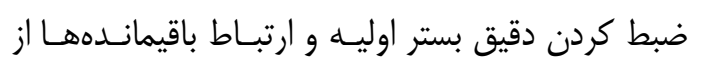

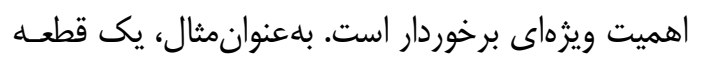
شكسته كلدان سفالى ممكن است يك شئ جذاب براى

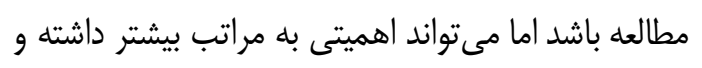

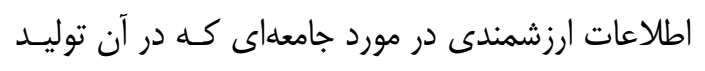

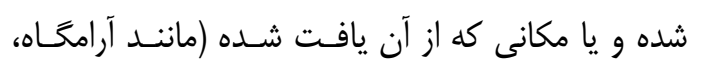

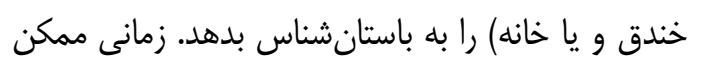

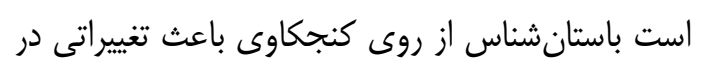

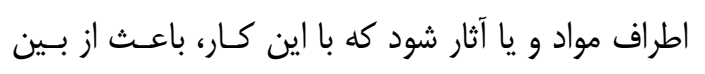

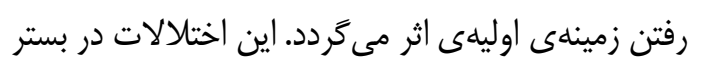

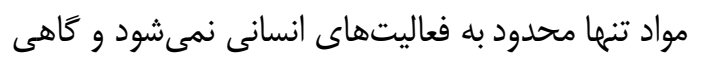

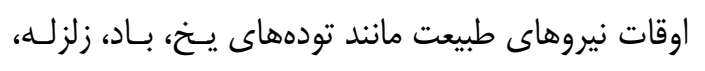

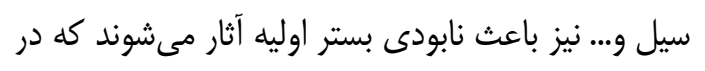

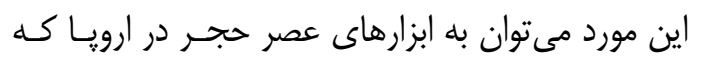

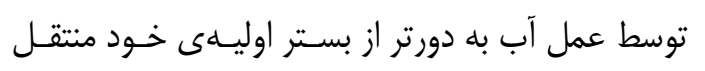

شدند اشاره نمود (Renfrew and Bahn, 2000). در اين ميان آثار ارزشـمندى، بــه دلايلى از قبيـل

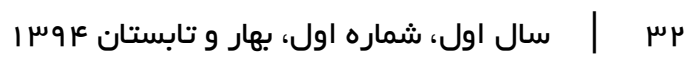


خراش از شاخصههاى فنسى و سـاختارى سـفالينههـاى

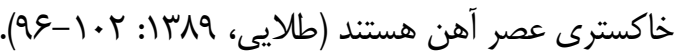

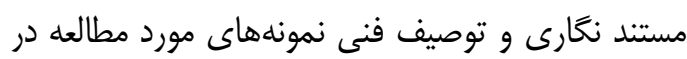

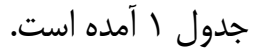

r-r - روشها و دستخاههای مورد استفاده بلهنظور بررسى و تعيين نوع و ميزان عناصر موجـود در

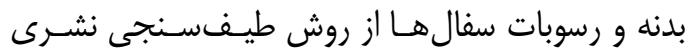

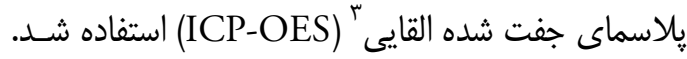

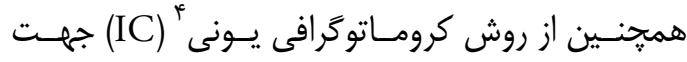
تجزيه آنيونهاى خُند اتمسى موجـود در سـفال هــا، و از

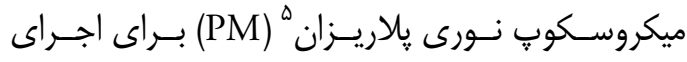

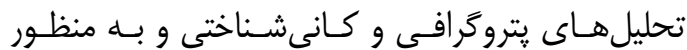
توصيف و آكاهى نسبى از دورهى فرهنكى سفالينههـاى

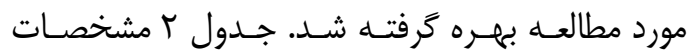
دستخاههاى مورد استفاده را نشان مى دهد. جهت انجام آزمايشهاى (ICP-OES)، ابتـدا هـ/ •

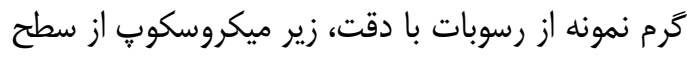

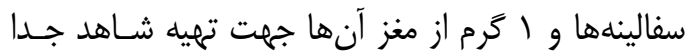

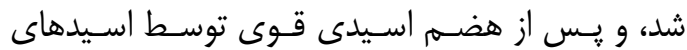
در يك سيستم $\left(\mathrm{HClO}_{4}+\mathrm{HNO}_{3}+\mathrm{HF}+\mathrm{HCl}\right)$ باز، نمونهها بدست آمـد ) Jeffery and Hutchinson, 1983). براى تسهيل در مرحله هضم اسيدى، نمونههـا

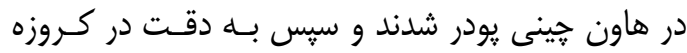

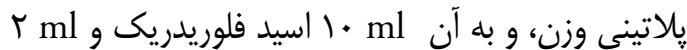
اسيد يركلريك اضافه شد. كروزهها روى حمام شن قرار كرفت تا اسيدهاى اضافهشده خشك شوند. سيس ml هl اسيد يركلريك اضافه مى شود و يـس

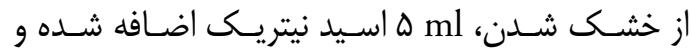
نمونهها در محلول rا نرمال اسيد كلريدريك (: هضم

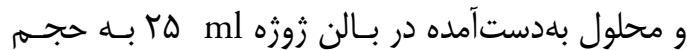

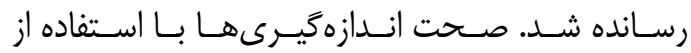

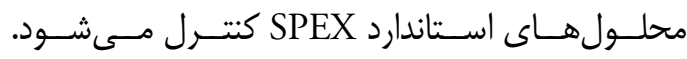
محلولهاى استاندارد قبل از استفاده به صورت تازه تهيه

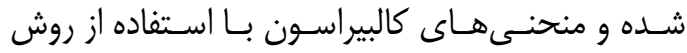
رَرسيون خطى رسم مى
مصنوعات باستانى بر مبناى رسـوبات و بقايـاى محسيط دفن در ايران صورت نخرفته و همجِنين كزارش خاصى

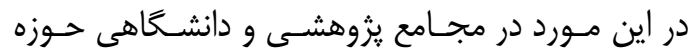

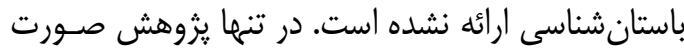

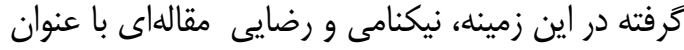
الجزيه عنصرى خاك باستانى دورهى مس - سنكى تيه زاغه براى شناسايى مكانهاى فعاليتهاى ويزهه" منتشر دان

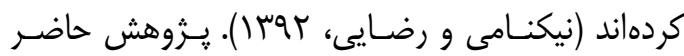

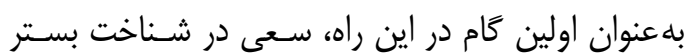
مصنوعات باستانى در ايران بر مبناى تحليلهاى علمى و أزمايشَاهى بستر سفال ها دارد كه به اين منظور هـ نمونه از سفالينههاى خاكسترى منسوب به عصر آهن متعلق به موزه ملى ايران باستان و گروه باستان شناسـى دانشـاه بير جند انتخاب و مورد بررسى آزمايشكاهى قرار كرَف فرتند.

\section{ץ- نمونهايى مطالعاتى، دستخاهها و روشهاى مورد استفاده}

در اين بخـش بــهـ معرفـى نمونسهـهـاى مـورد مطالعـه، روشهاى بهكار رفته جهت آناليز شيميايى آنها، نحوهى نمونى نمونهبردارى و شيوه آمادهسازى نمونـهـهـا بــراى آنـاليز

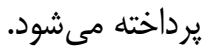

ب- - - معرفى نمونهها در ايـن يـروهش ه نمونسه از سـفالينهــاى خاكسـترى

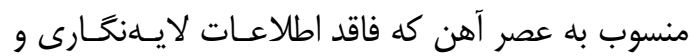
كاهنخارى باستانشناختى بوده و متعلق به مــوزه ايـران

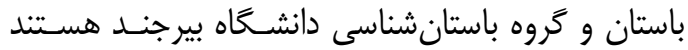

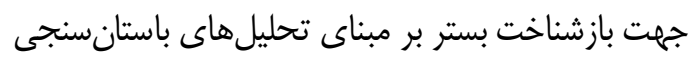

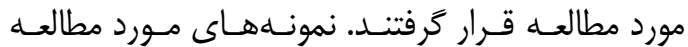
ويزگى هاى فرمى و تكنيكى سفالينههـاى خاكسـترى و

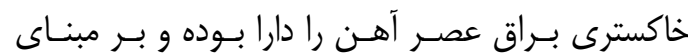
مطالعات يتروكرافى و كانى شناختى نيز، شباهت ساختارى إنى

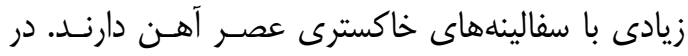

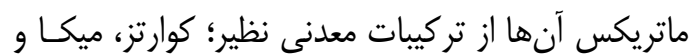

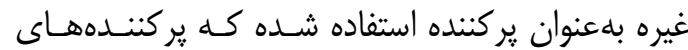

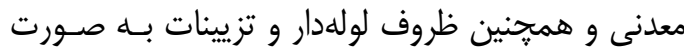


جلول (: معرفى و توصيف نمونهاى مورد مطالعه

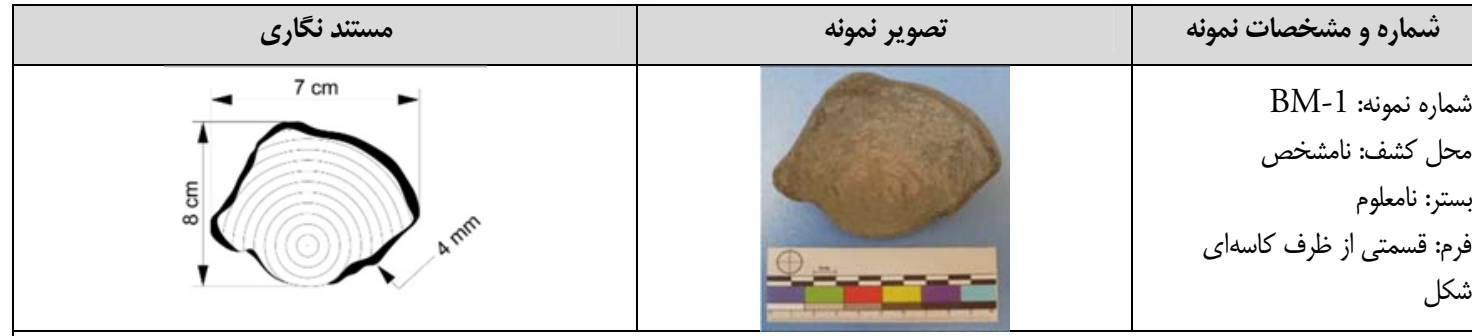

توصيف و توضيحات: نمونه قسمتى از يايه و شكم يك ظرف احتمالاً به فرم كاسه است كه فاقد هركونه تزئينات است و با توجه به فر فرم نسبتاً يكدست و

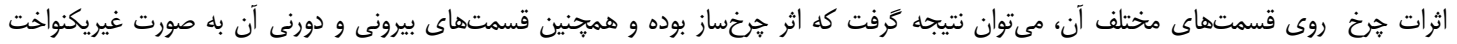
يوشيده از رسوبات سخت به رنخ خاكسترى روشن هستند.
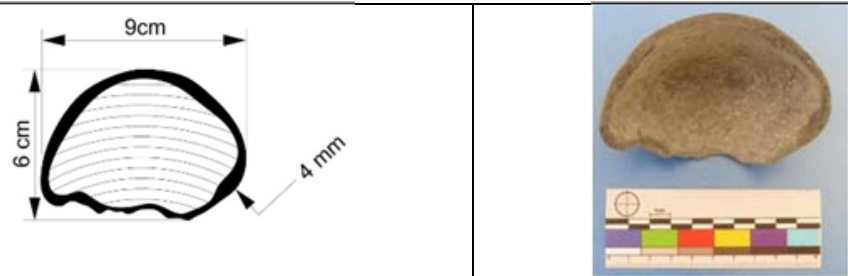

شماره نمونه: BM-2 محل كشف: نامشخص نش بستر: نامعلوم فرم: قسمتى از شكم ظرف نامعام

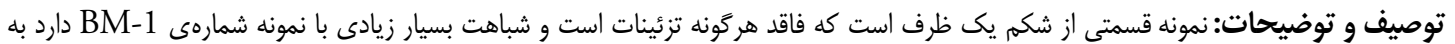

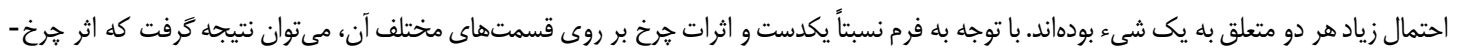

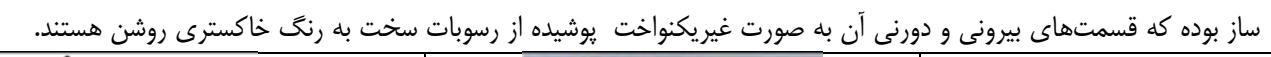
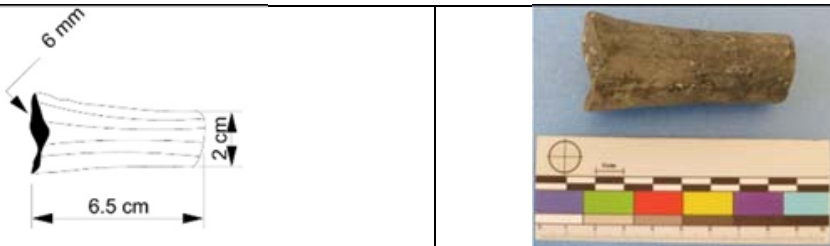

شماره نمونه: BM-3 محل كشف: نامشخص بستر: نامعلوم فرم: لوله يا آبريزكًاه يك ظرف

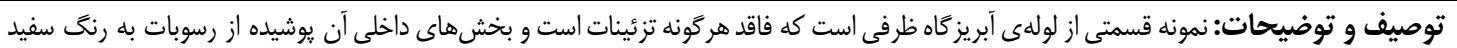

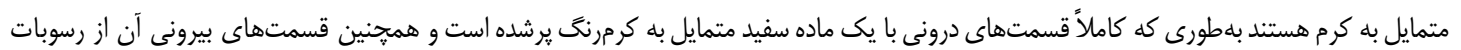
سفيد تيره و خاكسترى روشن به صورت غيريكنواخت يوشيده شده باست داست
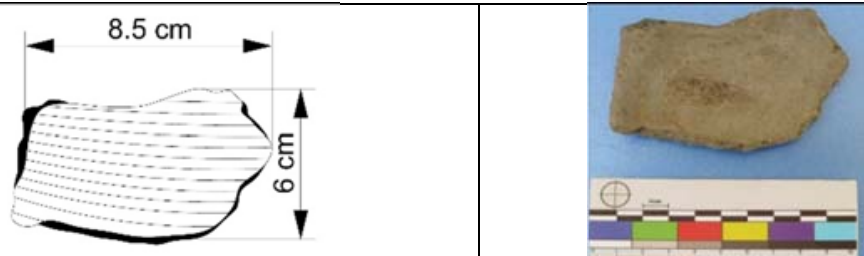

شماره نمونه: BM-4 محل كشف: نامشخص : بمان: بستر: نامعلوم فرم: بدنه

توصيف و توضيحات: نمونه داراى تزيينات هندسى (به شكل مثلث) در بخش بيرونى است كه به صورت خراش مكانيكى بر روى سطح آن ايجاد شدهاند

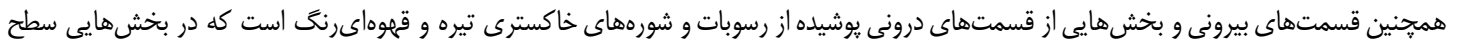

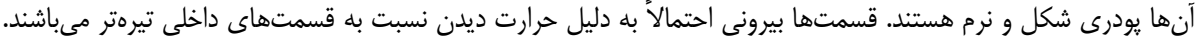
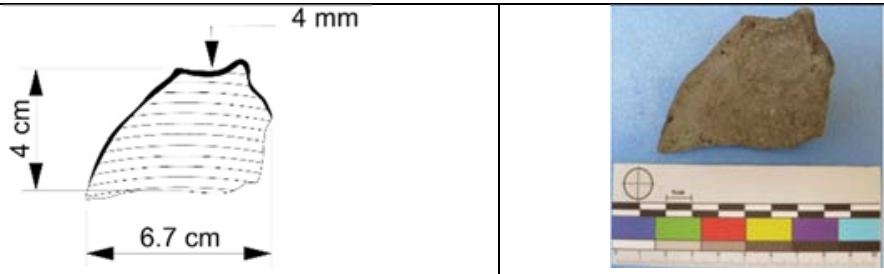

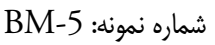
محل كشف: نامشخص: نماره بستر: نامعلوم فرم: بلدنه

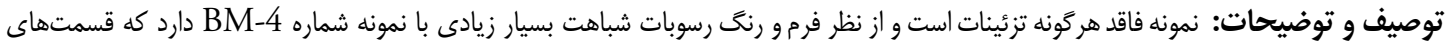

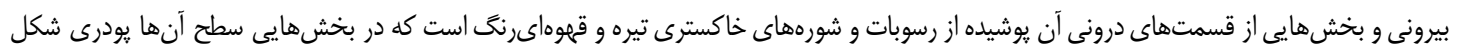


جلول r: مشخصات دستكاههاى مورد استفاده در يُوهش حاضر

\begin{tabular}{|c|c|c|c|}
\hline محل انجام آناليز & 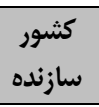 & مدل دستكاه & نوع آزمون \\
\hline شركت مطالعات مواد معدنى زر آزما تهران & 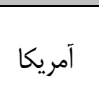 & HP 4500 & $\begin{array}{c}\text { طيفسنجى نشرى بلاسماى جفت شده القايى (OES } \\
\text { (OEP }\end{array}$ \\
\hline آزمايشكاه يتروكرافى دانشكده علوم طبيعى & زإين & $\begin{array}{l}\text { Olympus } \\
\text { (BX51TRF) }\end{array}$ & ميكروسكوب نورى يِاريزان (OPM) \\
\hline يزوهشكاه موادو انرزى & 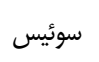 & Metrohm & كروماتوكرافى يونى \\
\hline
\end{tabular}

مورد مطالعه به صورت درصدى (جدول r) گزارش شده

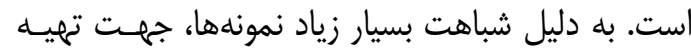

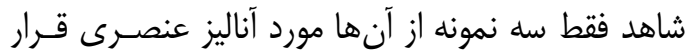
كرفت. بر مبناى نتايج آناليز عنصرى ICP-OES (جدول ب) غلظت عناصـر در نمونسهــاى BM-1 و همجنين BM-5 و BM-4 شباهت و همبستخى بسيار نزديكى دارند (شكلهاى ا و أ)، كه به دليل يايين بودن غلظت عناصر و قدرت آشكارسازى دستخاه ICP-OES در نمونههاى كمتر از يك گرم، ميزان عناصر يرمقدار در نمونه رسوبات به صورت ppm و در نمونهى شـاهد بــه

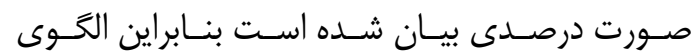
روشـمندى بــراى مقايسـهـ غلظـت عناصـر يرمقـدار در نمونههاى رسوبات با نمونلى شاهد نمىتوان تبيين نمود كه درنتيجه، تحليل دادهها با استفاده از عناصر كم مقدار و همجنين همبستخى بين عناصر در نمونهاى مشابه و

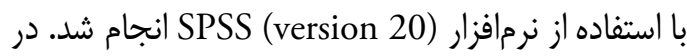
نمونههاى BM-1 و BM-2 عناصر آلومينيوم، سيليسيه، كلسيم و آهـن بـيشتـرين مقـادير عناصـر را تشـكيل مىدهند كه وجود درصد بالاى اين عناصر، به خصوص

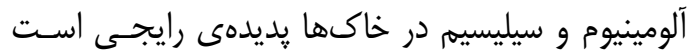
קراكه عناصر مذكور بيشترين فراوانسى را در يوسـتهى

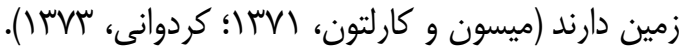

\section{- نمونههاى BM-1 و BM-2} بــر مبنــاى مطالعـهـى همبســتخى مقــادير عناصــر در

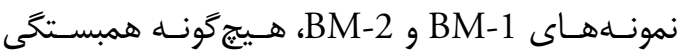
روشمندى بين عناصر يرمقدار در نمونههاى مذكور وجود ندارد تا بتوان فعاليتهاى انسانى كه موجب تغيير غلظت

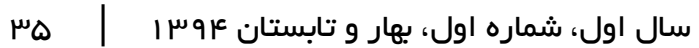

براى آماده سـازى نمونـهـهـا جهــت آنـاليز توسـط

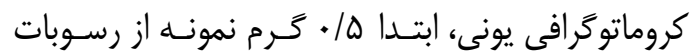

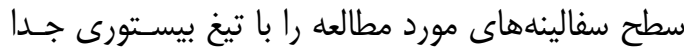
نموده و جهت تسهيل هضم اسيدى در هاون عقيق، يودر

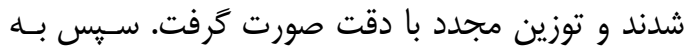
منظور جلوگيرى از جوش و خروش كربناتها ،ابتـدا در داخل بشر تفلونى، ب قطره HCl

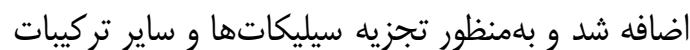

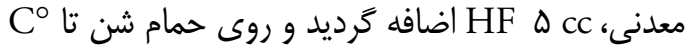

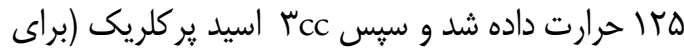

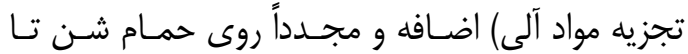
نزديك خشك شدن حرارت داده شد. نهايتاً توسط اسيد

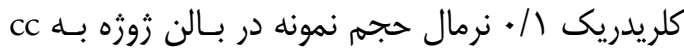
ه م رسانده شد.

\section{ب- نتايج و بحث}

\section{ץ-1 - آناليز نمونهها بــه روش طيـفسـنجى

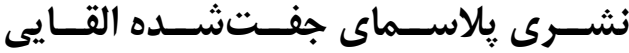 \\ (ICP-OES)}

طيفسنجى نشرى يلاسماى جفت شده القـايى (ICP(OES روشى نشرى براى آناليز همزمان عناصر در مواد و بافتهاى مختلف اسـت. شناسـايى و تعيـين غلظـت عناصر موجود در نمونههاى مورد مطالعه توسط دسـتخاه

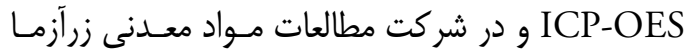
انجام شد. غلظت نمونههاى رسوبات آناليز شده در ايـن

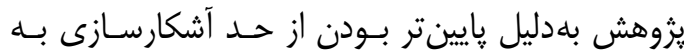
صورت درصدى، به صورت ppm ارائه شده (جدول ب)،

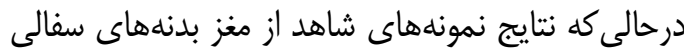


جدول س: نتايج آناليز رسوبات به روش ICP-OES و آناليز نمونهاى مغز سفالينهها (جهت تهيه شاهد) به روش ICP-OES

\begin{tabular}{|c|c|c|c|c|c|c|c|c|c|}
\hline \multicolumn{6}{|c|}{ نتايج آناليز رسوبات (ppm) } & \multicolumn{4}{|c|}{$\begin{array}{c}\text { نتايج آناليز نمونههاى مغز سفالينها } \\
\text { (ppm ورصد وزنى و (ppm }\end{array}$} \\
\hline عنصر & BM-1 & BM-2 & BM-3 & BM-4 & BM-5 & عنصر & BM-1 & BM-3 & BM-5 \\
\hline $\mathrm{Ag}$ & $r / \Lambda$ & $r / T$ &.$/ 19 q$ & $r / \Delta$ & $r / \varphi$ & $\mathrm{Ag}$ & $>r$ & Mr & $>r$ \\
\hline $\mathrm{Al}$ & FIrIS & fillr & $r q \varphi \cdot \Delta$ & 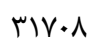 & mFil. & K & $\% r / r$ & $\% \Delta / r$ & $\% r / q$ \\
\hline $\mathrm{Ba}$ & equ & FNE & eqfe & זس人 & ArA & $\mathrm{Ba}$ & Q. & $p q$. & VAY \\
\hline $\mathrm{Ca}$ & $\Delta T G \cdot V$ & DrQFq & $\% 1$. & $r M . \cdot r$ & r..r & $\mathrm{Ca}$ & $\% \Delta / \kappa^{c}$ & $\% .9$ & $\% \boldsymbol{F} / \Lambda$ \\
\hline $\mathrm{Cu}$ & 190 & 198 & i) & ع & ITV & $\mathrm{Cu}$ & וזץ & $v^{c}$ & צrו \\
\hline $\mathrm{Fe}$ & VQTYI & VOTA. & |人rm|q & ergav & FYAFA & $\mathrm{Fe}$ & $\% я / \wedge$ & $\%$ & $\% \mathrm{~V} / \mathrm{r}$ \\
\hline $\mathrm{Mg}$ & $9 \Delta \Delta)^{2}$ & $9 \Delta \Delta V$ & MMI & $1 V \cdot 8 \Lambda$ & 19994 & $\mathrm{Mg}$ & $\% r / r$ & $\% \mu / \Delta$ & $\% r / r$ \\
\hline $\mathrm{Mn}$ & $1 \cdot r V$ & $1 \cdot m e$ & $\Delta \cdot r$ & $\Delta \cdot \Delta$ & DIIF & $\mathrm{Mn}$ & אז'ו & 0.9 & rır \\
\hline $\mathrm{Na}$ & Ir人qV & IrAeq & שqא & VTD. & VATa & $\mathrm{Na}$ & $\% \mathrm{~N} / \mathrm{r}$ & $\% \cdot / \Delta$ & $\%+/ V$ \\
\hline $\mathrm{P}$ & T.MTS & r...MF & $\Delta \& q$ & qVD & سوף & $\mathrm{P}$ & grvq & ه. & $\Lambda+r$ \\
\hline $\mathrm{Pb}$ & 91 & سو & 11 & is & سז & $\mathrm{Pb}$ & $\varepsilon_{D}$ & IV & $r q$ \\
\hline$S$ & Fel & Rr & lurq. & r. & squv & $S$ & $E \Delta$. & T. & 19V \\
\hline $\mathrm{Sb}$ & $r \Delta / r$ & $r q / r^{c}$ & $1 / \bullet$ & $1 / .9$ & $1 / \cdot 1$ & $\mathrm{Sb}$ & عس & Ir & rس \\
\hline $\mathrm{Sc}$ & $\mid q / 1$ & $18 /\left.\right|^{c}$ & $s / V$ & $|V /|$ & $\mathrm{IV} / \Delta$ & Sc & $\Delta f$ & 19 & 91 \\
\hline $\mathrm{Si}$ & NAMKN & NDTYI & QTKIF & g99TI & GNAIT & $\mathrm{Si}$ & $\% \Delta \wedge$ & $\% 19$ & $\% \Delta r$ \\
\hline $\mathrm{Sr}$ & NTE & $\Delta)^{4}$ & r). & DIT & prq & $\mathrm{Sr}$ & 194 & 19. & $r+v$ \\
\hline Th & $N D$ & $1 \mathrm{~V} / \mathrm{q}$ & س/m & $\mid \omega / r$ & $\mid f / s$ & Th & r) & 19 & 19 \\
\hline $\mathrm{Ti}$ & \&AV & rᄉ9V & שVוr & $\Delta \Lambda \backslash \Lambda$ & ه & $\mathrm{Ti}$ & $\% \cdot / V$ & $\% \cdot / \cdot 1$ & FQQ \\
\hline $\mathrm{U}$ & ه// & 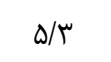 & $\Delta / 9$ & $f / \Delta$ & $c / v$ & $\mathrm{U}$ & $\cdot / 4$ & 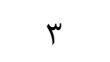 & $>+/ r$ \\
\hline $\mathrm{Zn}$ & 110 & 110 & $\Delta$. & $1 . c^{c}$ & 1.9 & $\mathrm{Zn}$ & IME & سع & 91 \\
\hline $\mathrm{Zr}$ & $M$ & $M$ & $\wedge$. & $v^{e}$ & VT & $\mathrm{Zr}$ & 11. & 1.1 & $1+1$ \\
\hline $\mathrm{K}$ & TYMF & TrEVE & $199 .$. & TERVT & TOSVY & $\mathrm{Al}$ & \% & $\% 19$ & $\% r$. \\
\hline
\end{tabular}

وجود دارد به طورى كه با افزايش مقدار فسفر در نمونسه BM-1

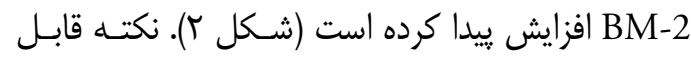

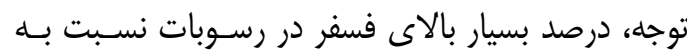

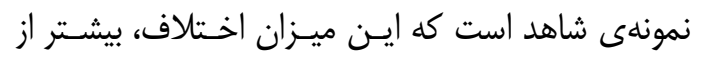

كمياب (كممقدار)، غير از فسفر و استرانسيم در رسوبات

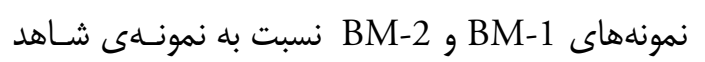
كمتر است. علاوه بر بالا بودن غلظت عناصـر فسـفر و و

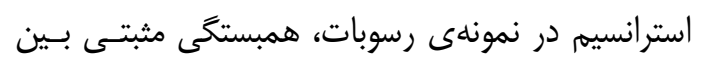

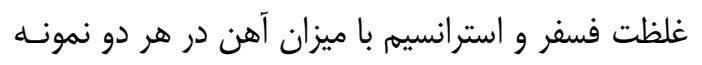




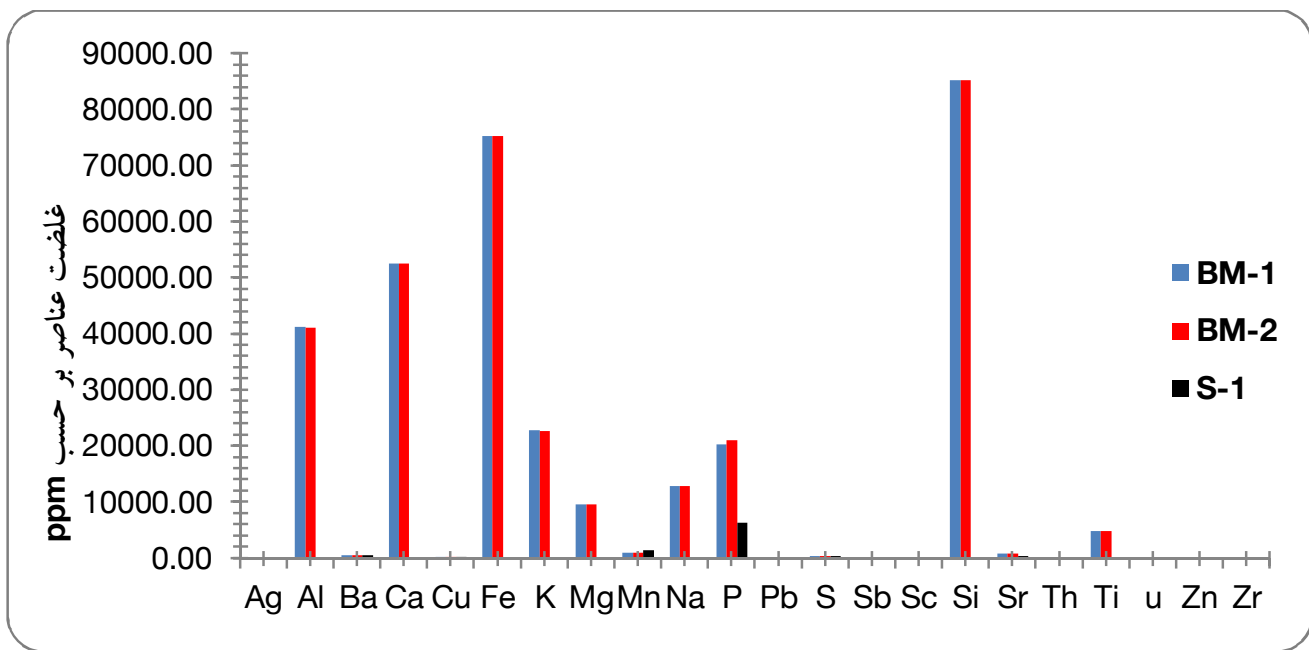

شكل (: غلظت عناصر در نمونه BM-1، BM-2 و نمونه شاهد S-1 بر مبناى نتايج ICP-OES

نمونهى شاهد از رسوبات نمونهى BM-3 بيشـتر اسـت

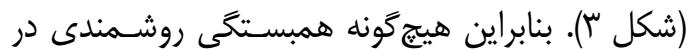
مقادير تمامى عناصر (غير از كلسيم و گَّرد) در نمونهى

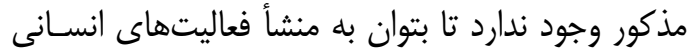
صورت گرفته در بستر كشف اثر نسبت داد.

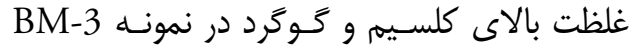
نسبت با نمونهى شاهد، نشـان از كشـف اثـر در بافت حاوى تركيبات كلسيمدار نظير نقاط سكونت و يز و است همجنين درصد بالاى گو گرد مي تواند مربوط به تركيباتى همجون سولفات كلسيم يا محصول واكنش

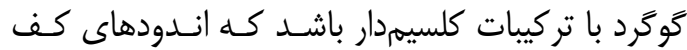
مناطق سكونت گاهى در بسيارى از مكانهـاى باسـتانى

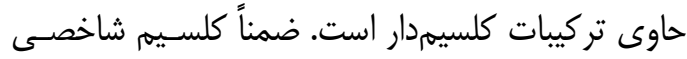
بهمنظور سنجش نهشتهاى ناشـى از فعاليـت انسـانى

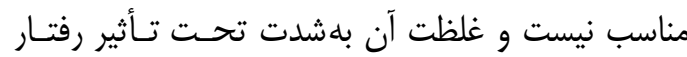

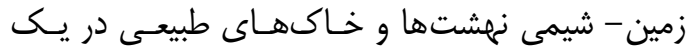

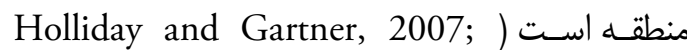
Hutson, 2004 گوگرد و همهنين بالا بـودن غلظت يـون كربنـات در

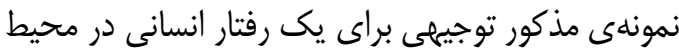

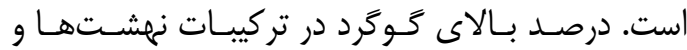
خاكهاى انسانزاد مربوط به فعاليتهايى اسـت كـهـ در

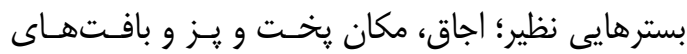
داراى خاكستر فراوان (مكانهاى صنعتى) است (نيكنامى

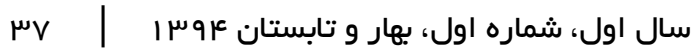

مقدارى است كه مربوط به خاى زمينزاد (طبيعى) تببين

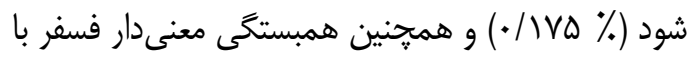
استرانسيم و آهن نشان از فعاليتهاى انسانزاد در فر بستر كشف نمونههاى مذكور دارد. درصد بالاى فسفر مى تواند

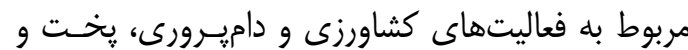

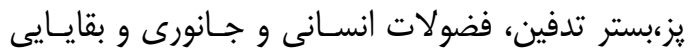

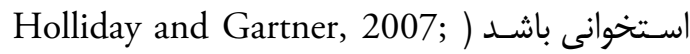
بـells, 2004; Parnell, 2001 نمونههاى BM-1 و BM-2 بهدليل درصد بالاى فسـفر در تركيب رسوبات آنها و همجنين همبسـتخى مثبـت

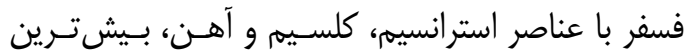

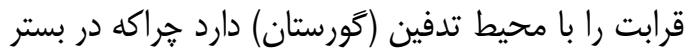
كورستان، تجزيه اجساد و انجام فعاليتهاى آيينى، نظير

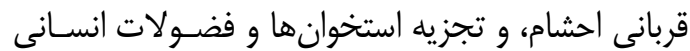
باعث افزايش يونهاى فسفات و نيترات و عناصر آهـن،

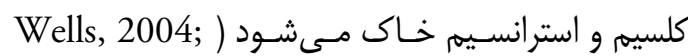

.(Parnell, 2001

\section{- نمونه}

عنصر كلسيم در نمونه BM-3 بيشترين مقدار را در بين عناصر شناسايى شده دارد كه ميزان آن • ا درصد بوده و نسبت به نمونهى شاهد أ درصد بيشتر است. همجنـين

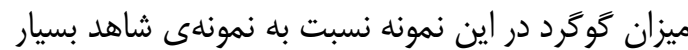
بيشتر است. غلظت ساير عناصـر بـهـ صـورت نسـبى در 

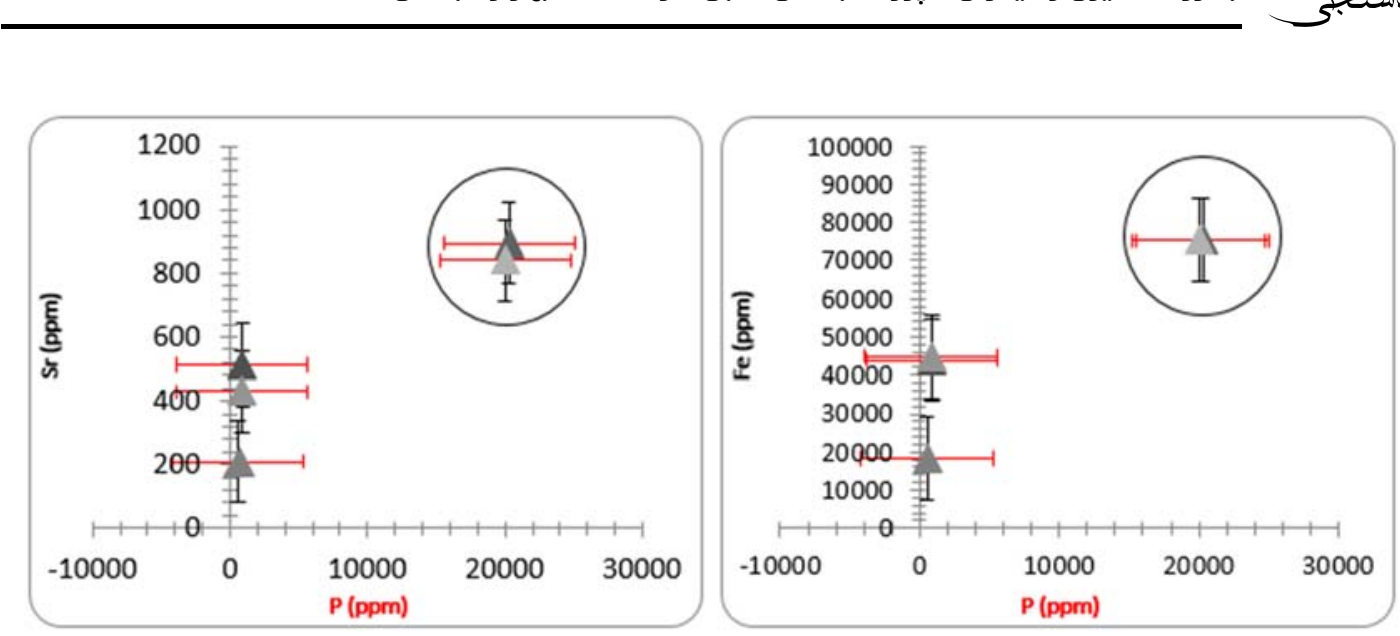

شكل ז: همبستخى آهن و فسفر (راست) و همبستخى استرانسيم و فسفر (ج) در نمونهاى BM-1 و BM-2

اثر دارند. بنابراين، درصد بسيار بالاى كلسيه در نمونهى

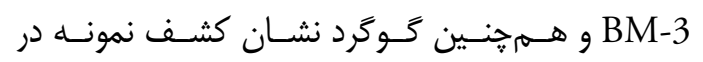
بسترهاى سكونت كاهى است.

\section{BM-5 BM-4 نمونه} غلظت گوخرد در رسوبات نمونههاى مذكور بسيار بيشتر

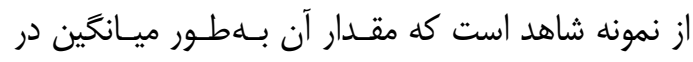

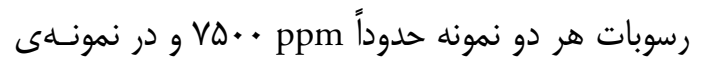

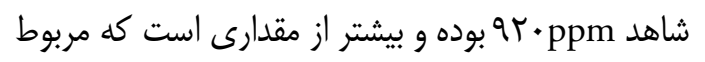
به تركيبات ليتوزنيك (خاى زمينزاد) باشـد (شـكل عاء). علاوه بر اين همبستخى مثبت و معنى دارى بين عناصـر

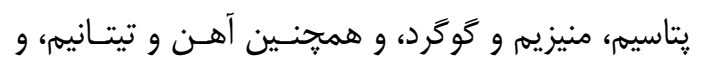

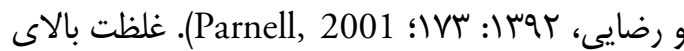
عنصر گَگرد در يك نمونه را بلتنهايى نمىتوان ناشى از

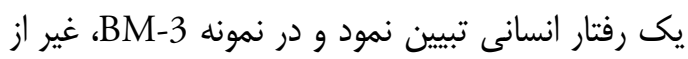

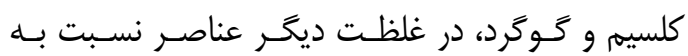
نمونهى شاهد تغيير قابل تمايزى وجـود نـدارد بنـابراين

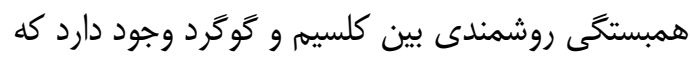

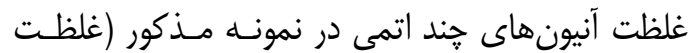

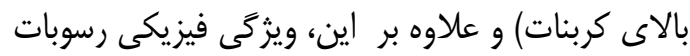

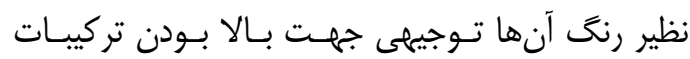

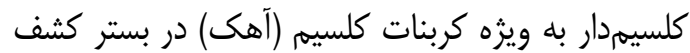

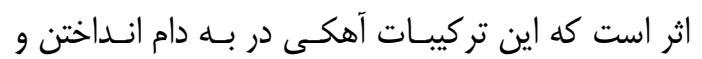
حفظ عناصر ناشى از فعاليتهاى انسانى در بستر كشف،

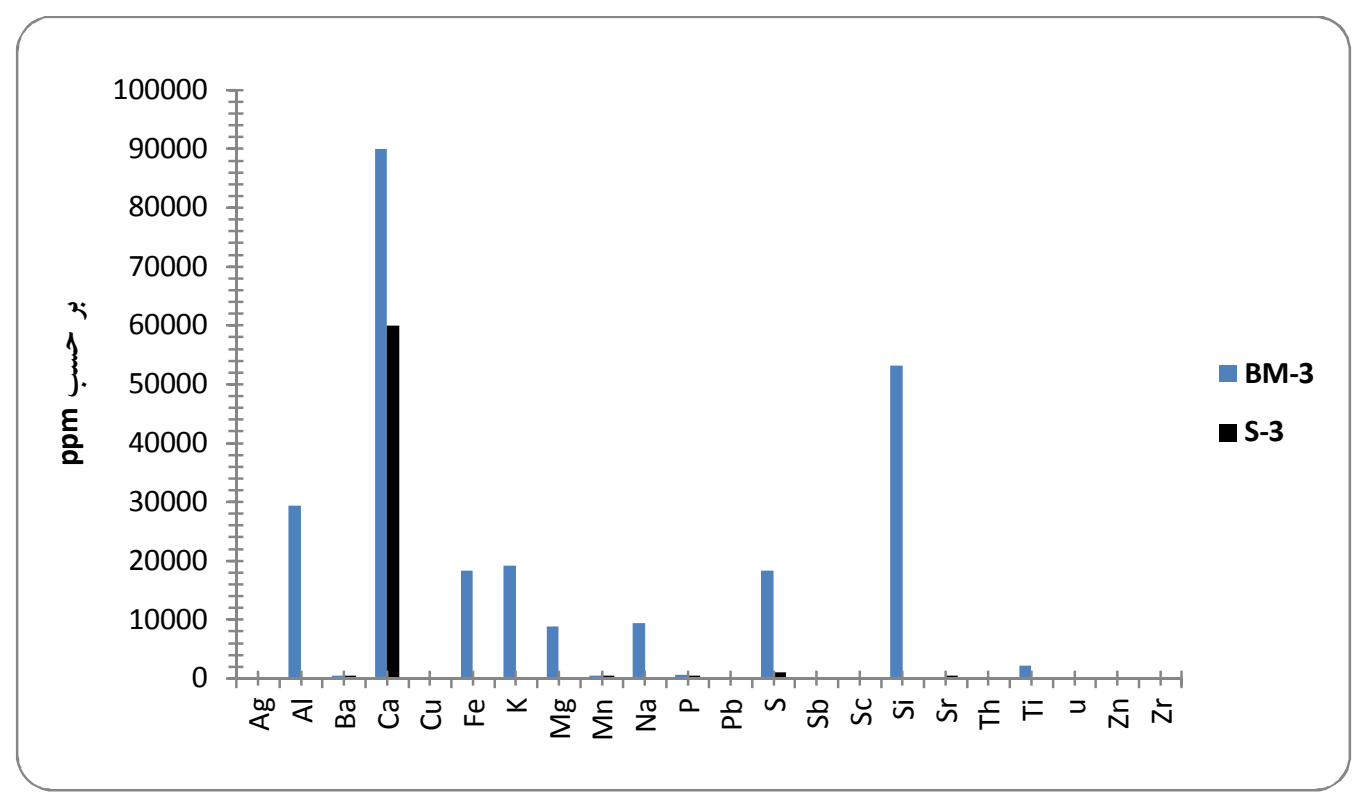

شكل س: غلظت عناصر در نمونه BM-3 و نمونه شاهد S-3 بر مبناى نتايج ICP-OES 


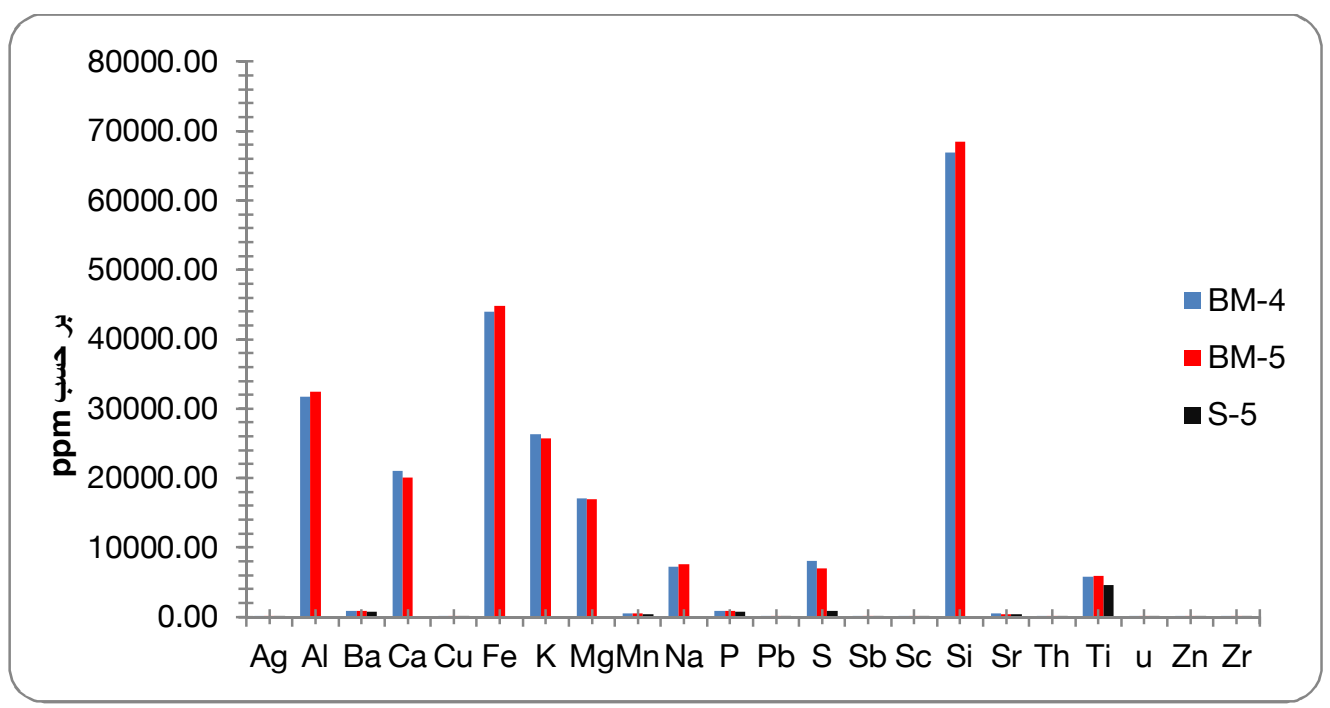

شكل عا: غلظت عناصر در نمونه BM-4 BM-5 ونمونه شاهد S-5 بر مبناى نتايج ICP-OES

غلظت گوگرد در نهشت باستانى مرتبط با حرارت و

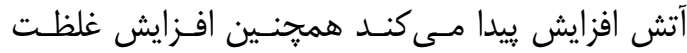
يتاسيهم و منيزيم مربوط به خاكستر سوختن خوب و زغال

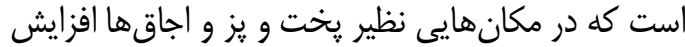
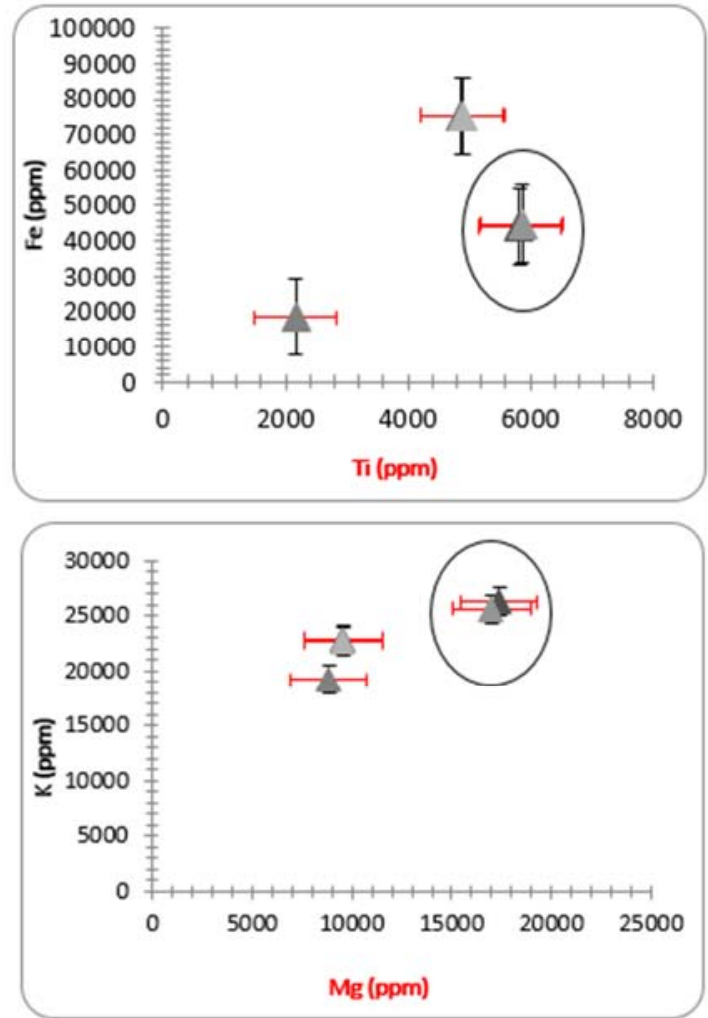

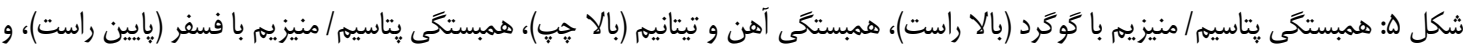

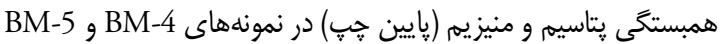

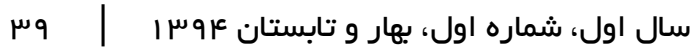
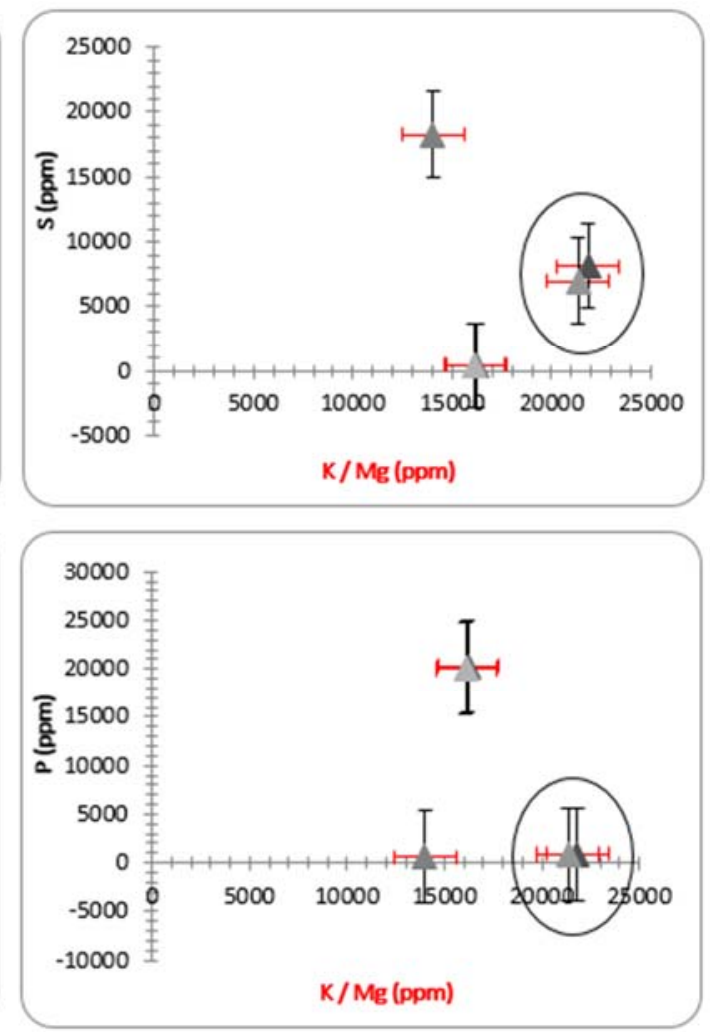

همبستخى منفى بين يتاسـيهم و منيـزيهم بـا سيليسـم در

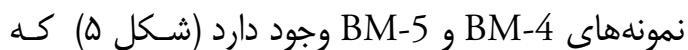
نشان از فعاليت انسانى ويثهاى در بستر كشف نمونههاى نامبرده است. 

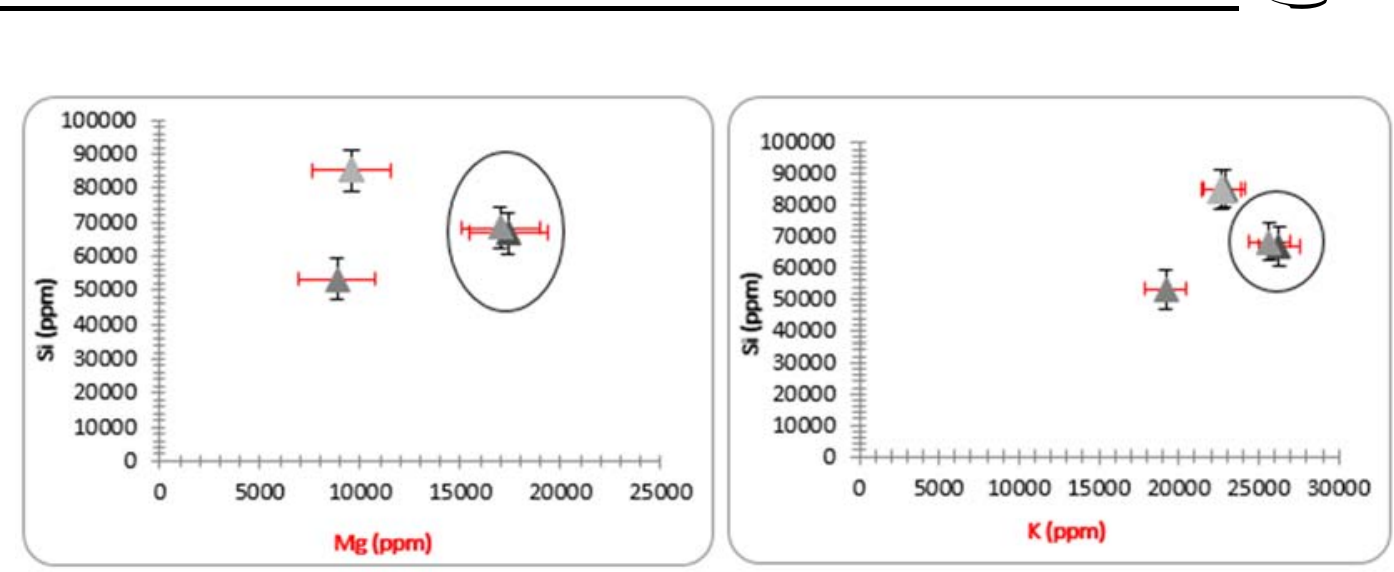

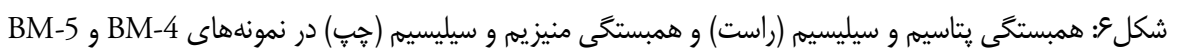

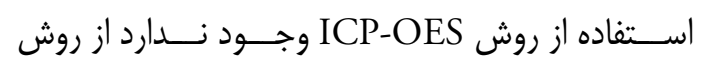
كروماتوكرافى يونى استفاده شد. (جدول عاء). در نمونههاى BM-1 و BM-2 غلظت بسيار بالاى

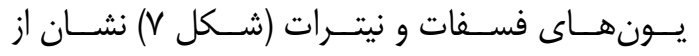

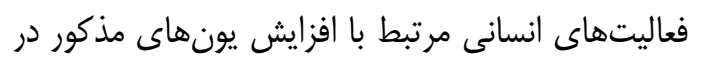

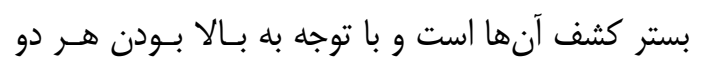
يون فسفات و نيترات و همجنين نتايج تجزيه عنصرى، نشان از كشف اثر در محيط تدفين است كـهـ بــهـ دليـل تجزيه اجساد يون فسـفات در محـيط، و نيـز بــــ دليـل

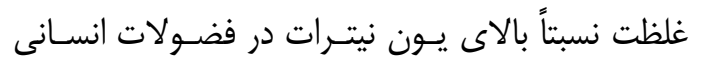

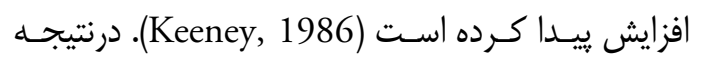

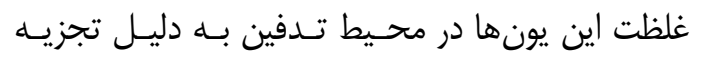

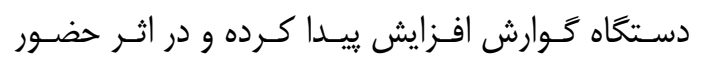

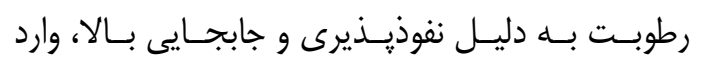

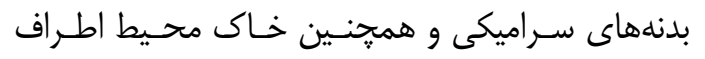
مى شود. همجنين يون نيترات در خاك طبيعى به صورت

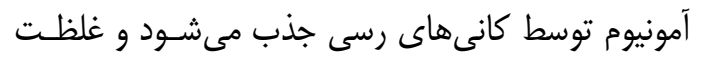
بالاى آن به صورت نيترات اغلب مربوط به فيه فعاليتهـاى

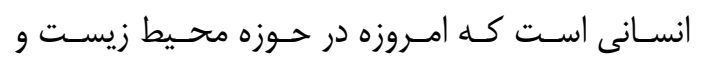
زمين شناسى جهت سنجش آلودگى آبهاى زير زمينى

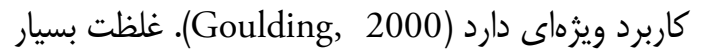

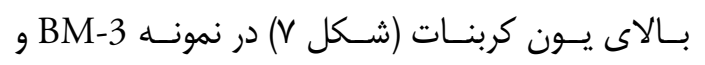

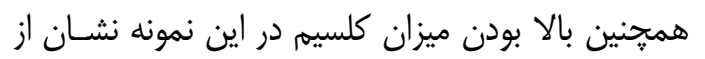
كشف اثر در بستر داراى كربنات كلسيم (آهك) بالا است كه در بافتهاى سكونت كاهى، آشيزخانه، مصالح در بناها

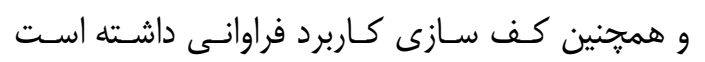

.(Holliday and Gartner, 2007; King, 2007)
King, 2007; Holliday and Gartner, ) بيدا مى كنند (2007; Wells, 2004 همجنين، در بافتهاى سوخته و حرارت ديده، مواد

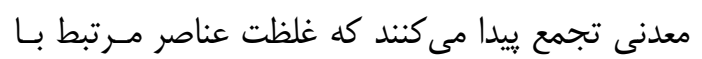

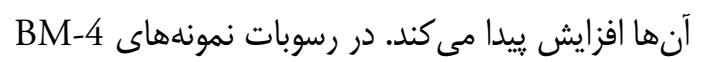
و BM-5 غلظت عناصرى نظير؛ فسفر، منخنز، تيتانيم و روى نسبت به نمونهى شاهد بيشتر اسـت (شـكل ها هان و همجنين همبستخى مثبتى بين تيتانيم و آهن وجود دارد كه اين همبستخى معنى دار در هر دو نمونه وجود داشته و

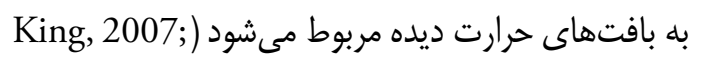
.Macphail et al., 2006 همبسـتخى معنسىارى بـين يتاسـيم و منيـزيم بـاــا

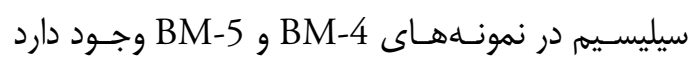

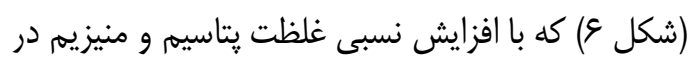

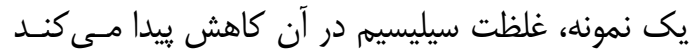

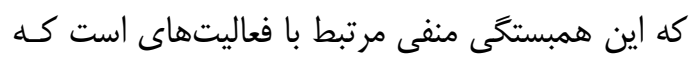
در آنها غلظت سليسيم كاهش ييدا مى كند (نيكنـامى و

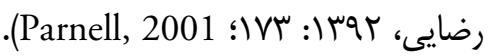

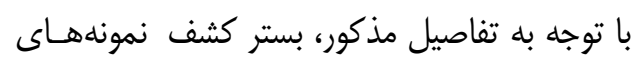

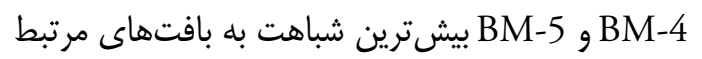

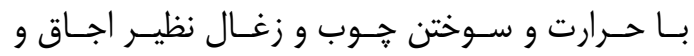
مكانهاى يخت و يز را دارند.

\section{ץ-ץ- آناليز نمونههاى مورد مطالعه به روش كروماتو تر افى يونى تمونى}

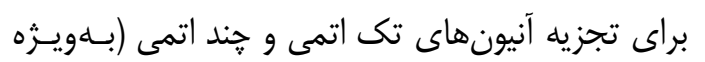

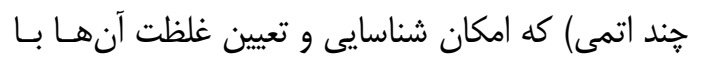

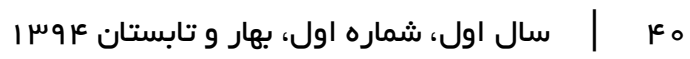


جدول عا: نتايج آناليز رسوبات به روش كروماتوكرافى يونى

\begin{tabular}{|c|c|c|c|c|c|c|}
\hline \multirow{2}{*}{ نمونه } & \multicolumn{6}{|c|}{ آنيون (ppm) } \\
\hline & $F$ & $\mathrm{NO}_{3}^{-}$ & $\mathrm{PO}_{4}^{3-}$ & $\mathrm{CO}_{3}^{2-}$ & $\mathrm{SO}_{4}^{2-}$ & $\mathrm{SO}_{3}^{2-} / \mathrm{S}$ \\
\hline MB-1 & (rv & pqvi. & $\Delta R+\Lambda$ & NAVT & eVt & 1Tr \\
\hline MB-2 & IFT & 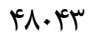 & DTDFV & $1+9 \Delta$ & pq. & $q+V$ \\
\hline MB-3 & MEDST & 94 & gQT & $9 \Delta \wedge \vee{ }^{2}$ & $1 . r .$. & $1+v 9$ \\
\hline MB-4 & $\Delta F$ & אזו & FTAF & 9901 & 901 & EIFVA \\
\hline MB-5 & 99 & $1 \cdot 0$ & r.9V & $v^{\pi} \cdot \Delta$ & git & DQAFV \\
\hline
\end{tabular}

يـونهـا نيـز دارد ) May and Jones, 2006; Wells,

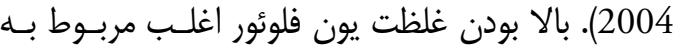

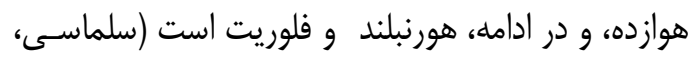

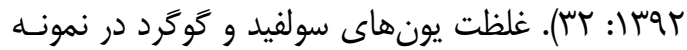
خاك ليتوزنيك و زمين -شـيمى كـانىهـاى موجـود در محيط است و علامتى مناسب جهت فعاليتهاى انسانى

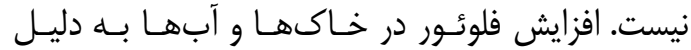

عاوه بر بالا بودن غلظت كربنات در نمونه BM-3، غلظت يونهاى سولفات و فلوئور در آن هم نسـبتاً بـالا است. بالا بودن غلظت سولفات ارتباط مستقيمى با بـالا بودن ميزان گَگرد در اين نمونه دارد كه به دليل وجـود

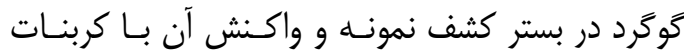
كلسيم، سولفات كلسيم ايجاد مىشود كه ايـن كربنـات كلسيم (آهك) نقش مهمى در حفــ و بــهـ دام انــاختن

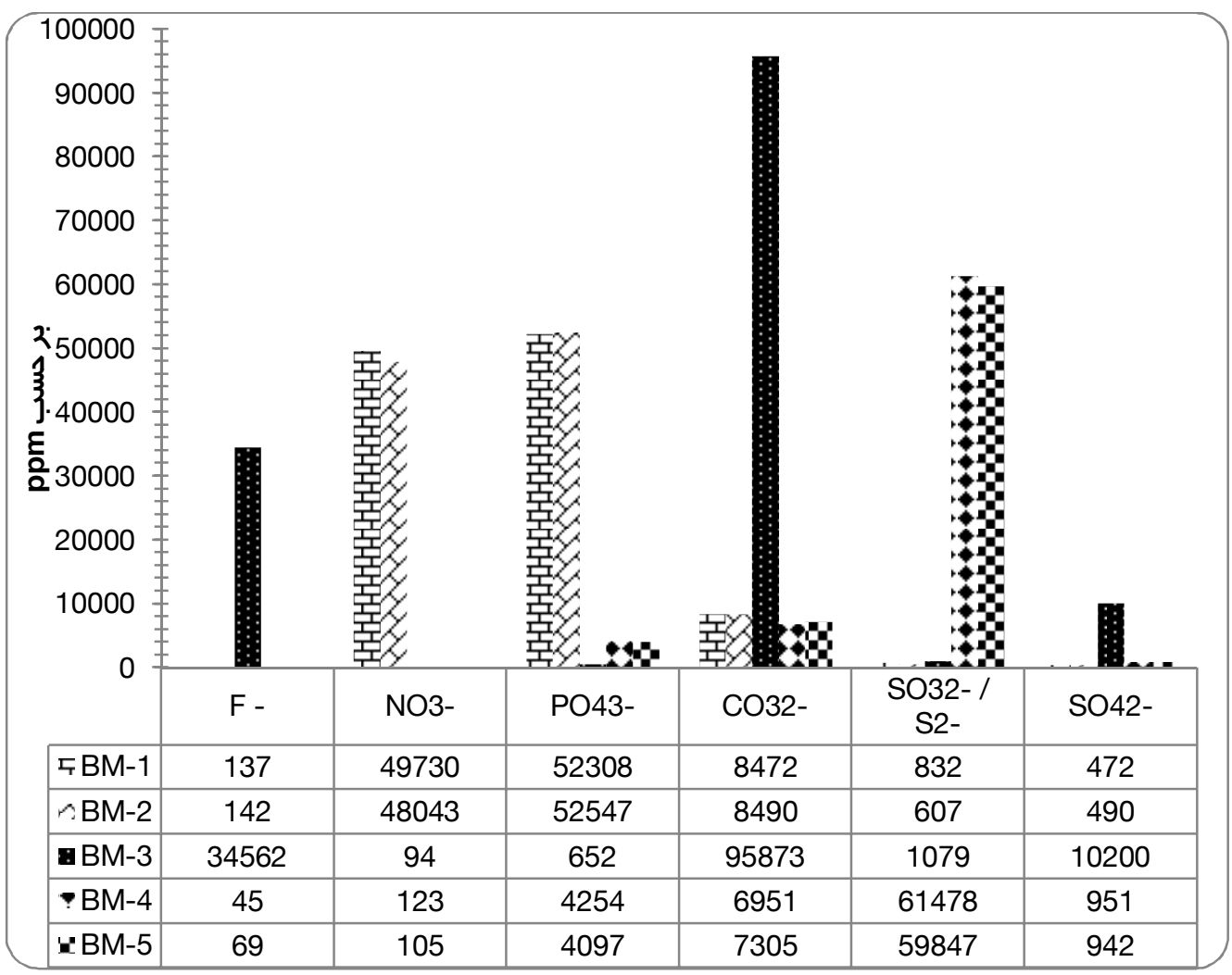

شكل V: غلظت آنيونهاى جند اتمى (تركيبى) در نمونههاى مورد مطالعه

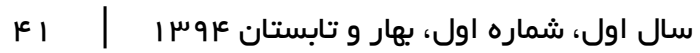


سه نمونه مقطع نازك تهيه شد به اين منظور ابتدا قطعه

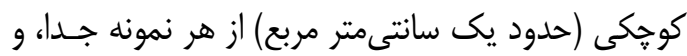

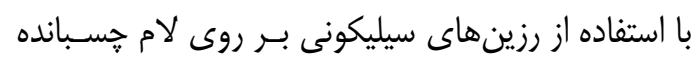

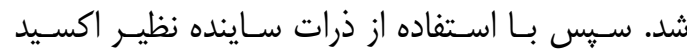

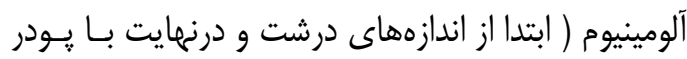

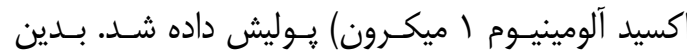

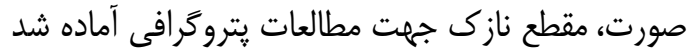

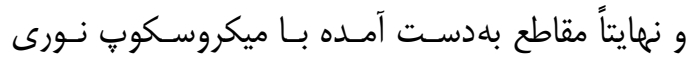
يلاريزان مطالعه و بررسى شدند. بررسى يتروكرافى مقاطع نازك در هر سه نمونـه از

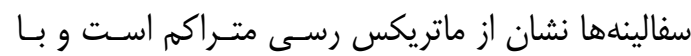

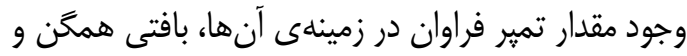
يكدست داشته و تميرهاى به كار رفته در ساختار آنهـا

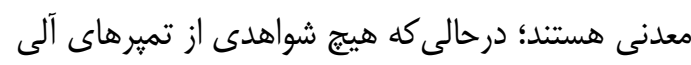

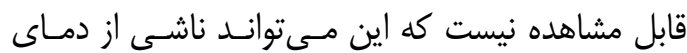
بالاى كوره در هنكام يخت اين سفال ها باشد. بر مبناى

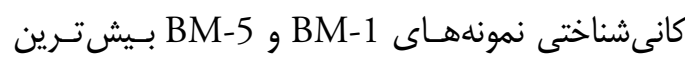

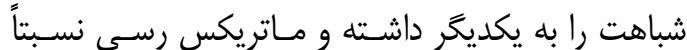

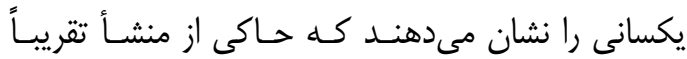

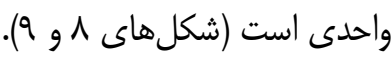
تصاوير كانى شناختى اين نمونه BM-3 على فئمسم

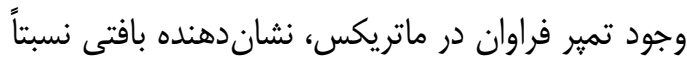

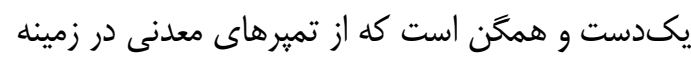

انحلال كانىها حاوى فلوئور است و آبهاى حاوى يون

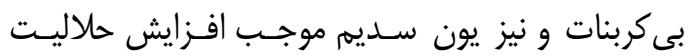

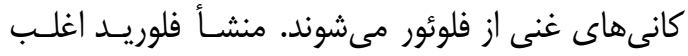

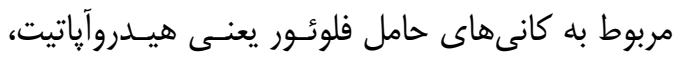

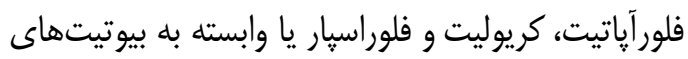

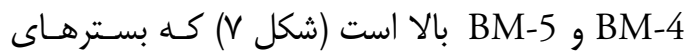

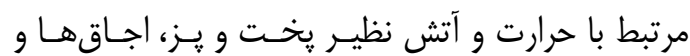

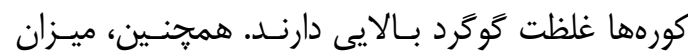
فسفات در اين نمونهها نسبتاً بالا است كه فسفات بـالا

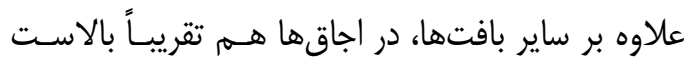

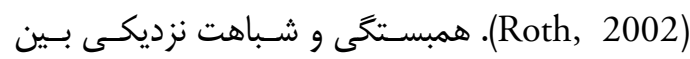
كََّرد و عناصر شناسايى شده نظير يتاسيم و منيزيم كه

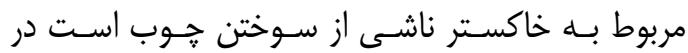

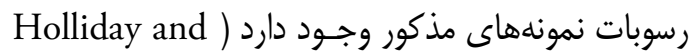
Gartner, 2007; King, 2007; Knudson et al.

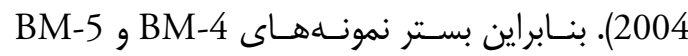
بيشترين شباهت با بافتهاى مرتبط با حرارت و آتش،

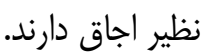

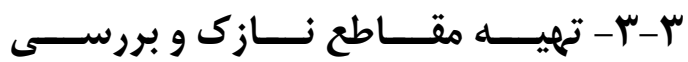
ميكروسكويبى نمونه هاى مورد مطالعه

براى بررسى يتروگر افى و كانىشناختى سـفالينههــا

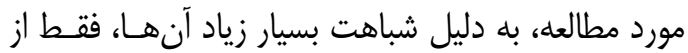

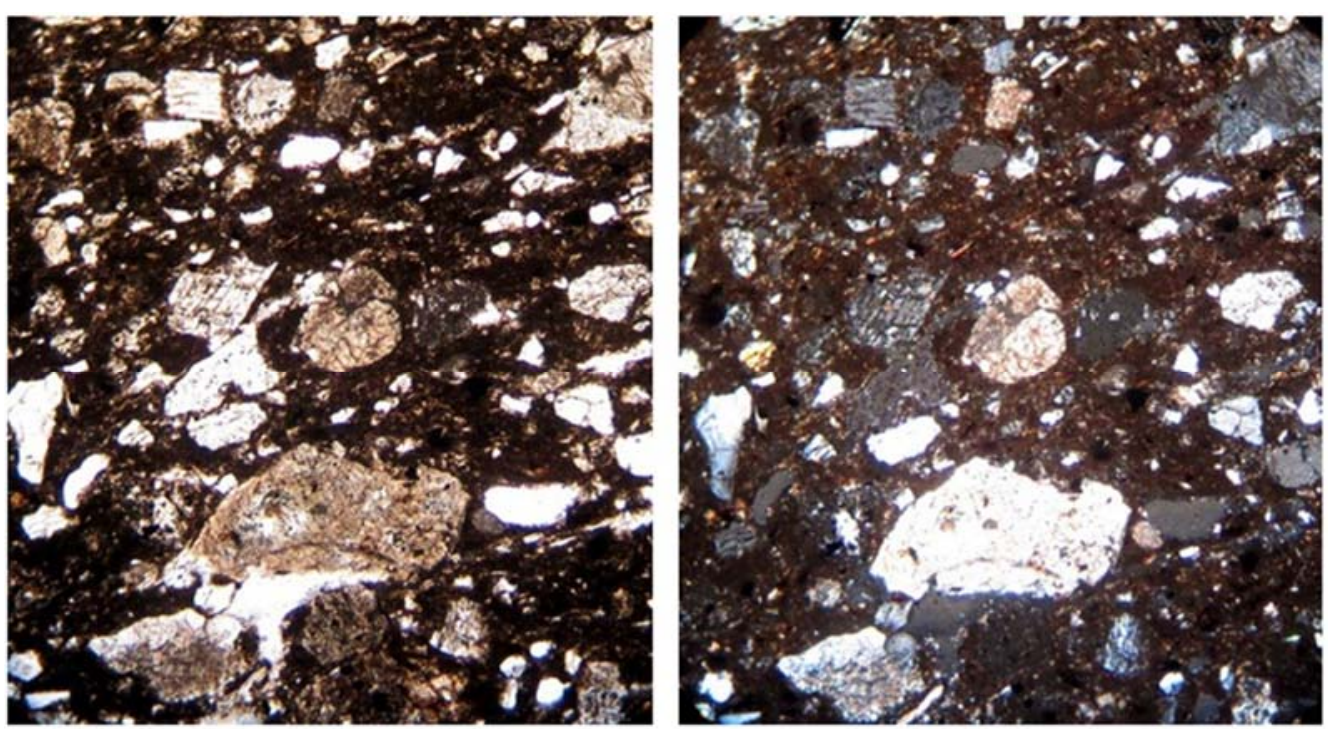

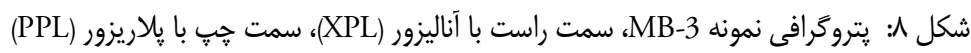



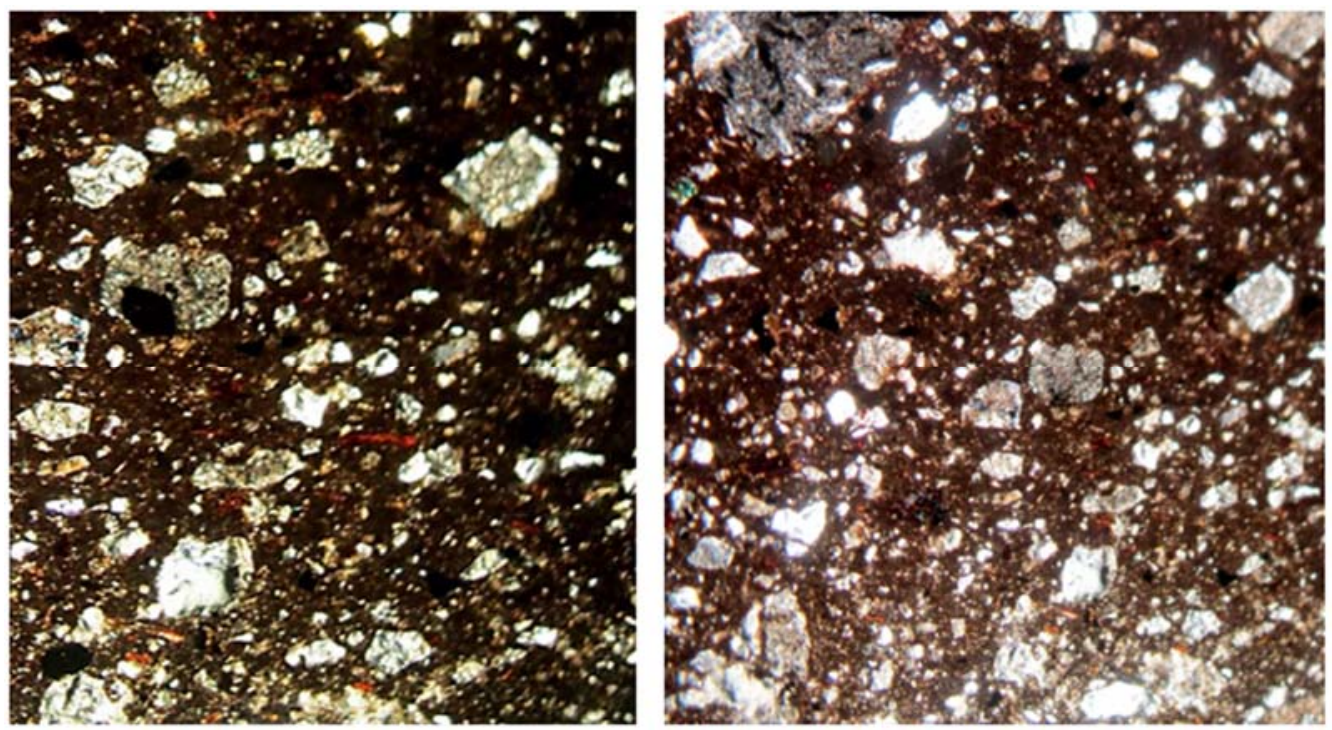

شكل ج: يتروكَرافى نمونه MB-1 (سمت راست، با آناليزور) و نمونه MB-5 (سمت جِ، با آناليزور)

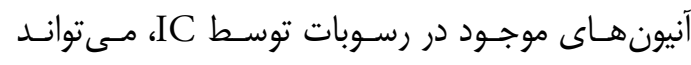
روشى سودمند براى شناسايى بستر اين مـواد باشـــ در

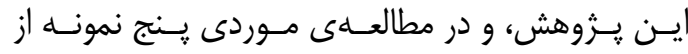

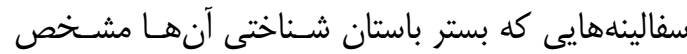

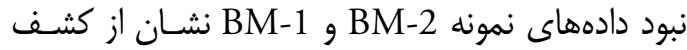
آنها در بسترهاى با غلظت بالاى يونهـاى فسـفات و ادنان

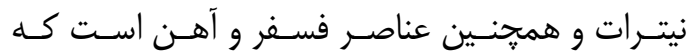

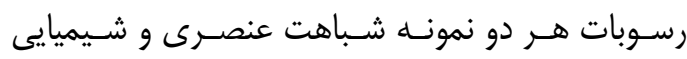

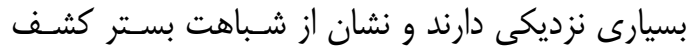

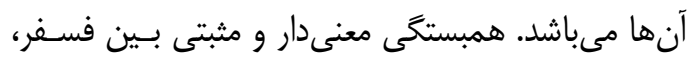

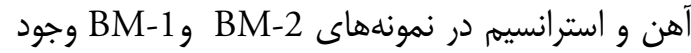

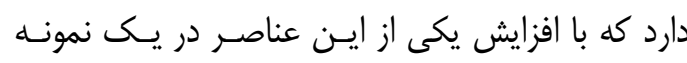

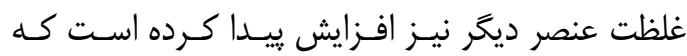

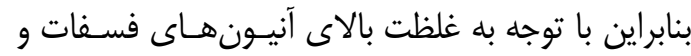

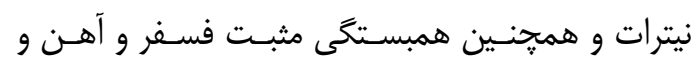

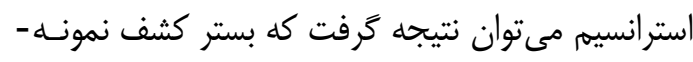

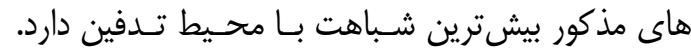

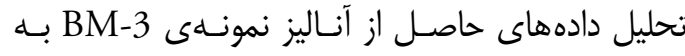

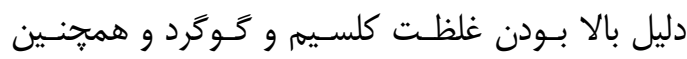

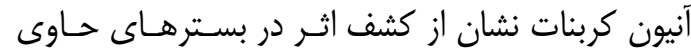

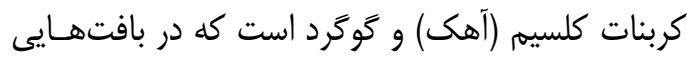

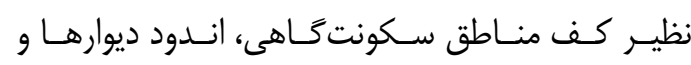

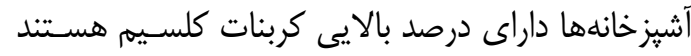

رسى آن به كار رفته است و كـانىهـاى؛ كـوارتز، ميكـا،

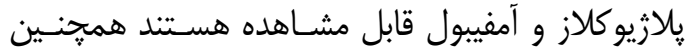
بسيارى از كانىهاى مورد استفاده تمبرهايى به صورت دانه درشت هستند درحالى كه ماتريكس تيره رنح نشان از شرايط يخت احيا است.

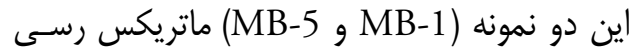

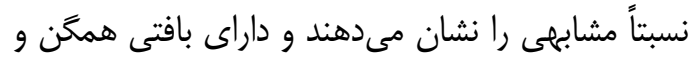

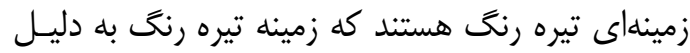

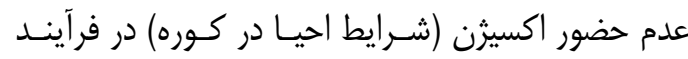
يخت ايجاد شده است. تمير بلهكار رفته در زمينهى رسى رسى إنى

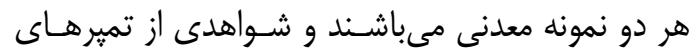

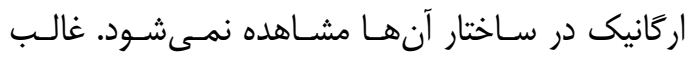

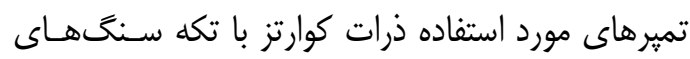

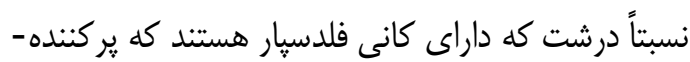

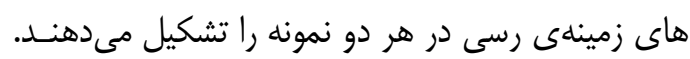

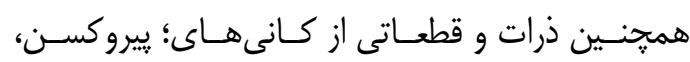
קيلازيوكلاز، آمفيبول، آندزيت و به مقدار جزئى اوليـوين،

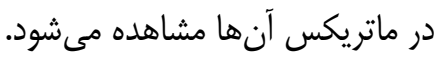

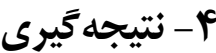

نتايج نشان دادند كه مطالعات آزمايشگاهى نوع و مقــدار عناصر تشكيل دهندهى رسوبات سفال هـا بـا اسـتفاده از نـاز روشهاى آناليز عنصرى ICP-OES و تعيـين غلظـت

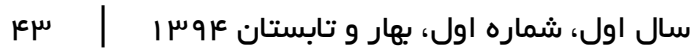




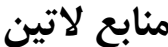

Dunning, N. P. (1993). Ancient Maya Anthrosols, soil phosphate testing and land use. In: Foss, J. E., Timpson, M. E., Morris, M. W. (eds). Proceedings of the first international conference on Pedo-Archaeology. University of Tennessee, Knoxville. Special publications, 203-211.

Eidt, R. C. (1985). Theoretical and practical considerations in the analysis of anthrosols. In Rapp, G., Gifford, Jr., J. A. (eds.), Archaeological Geology. Yale University press, 155-190.

Goulding, K. (2000). Nitrate leaching from arable and horticultural land. Soil Use and Management, (16), 145-151.

Holliday, V. T., Gartner, W. G. (2007). Methods of soil $\mathrm{P}$ analysis in archaeology. Journal of $A r-$ chaeological Science, (34), 301-333.

Hutson, S. R. (2004). Dwelling and subjectification at the ancient urban center of chunchucmil, Yucatan. Mexico. Doctoral Thesis, Department of Anthropology, University of California, Berkeley.

Jeffery, P., Hutchinson, G. (1983). Chemical methods of rock analysis. Third edition, 374.

Keeney, D. R. (1986). Nitrate in Ground WaterAgricultural Contribution and Control, In: Proceedings of the Conference on Agricultural Impacts on Ground Water. National water well association, Dublin, Ohio, 329-351.

King, S. M. (2007). The spatial organization of food sharing in early post classic households: an application of soil chemistry in ancient Oaxaxa. Journal of Archaeological Science, (34), 1-16.

Knudson, K. J., Frink, L., Hoffman, B. W., Price, T. D. (2004), Chemical characterization of arctic soils, activity area analysis in contemporary Yupikfish camps using ICP-AES. Journal of Archaeological Science, (31), 443-456.

Macphail, R. I., Cruise. G. M., Allen, M. J., Linderholm, J., Reynolds, P. (2006) Archaeological soil and pollen analysis of experimental floor deposits. Journal of Archaeological Science, (31), 175-191.

May, E., Jones, M. (2006). Conservation Science: Heritage Materials. Royal Society of Chemistry. 218-225.

Parnell, J. J. (2001). Soil chemical analysis of activity areas in the archaeological site of Piedras Negras, Guatemala. Brigham Young University, 32-64.

Renfrew, C., Bahn, P. (2000). Archaeology: theories, methods and practice. Thames and Hudson, London.

$$
\begin{aligned}
& \text { و با توجه به بالا بـودن غلظـت آنيـونهـاى كربنـات و }
\end{aligned}
$$

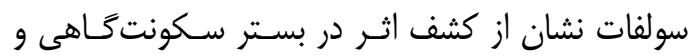

$$
\begin{aligned}
& \text { همجوار با مكانهاى حرارت ديده نظير اجاقهـا اسـت. }
\end{aligned}
$$

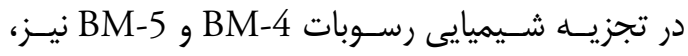

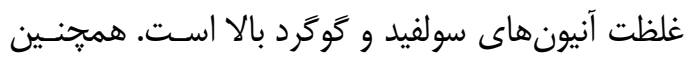

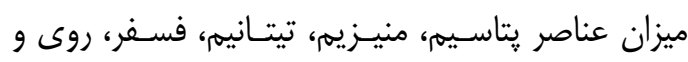

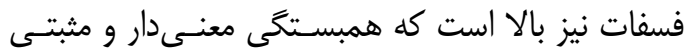

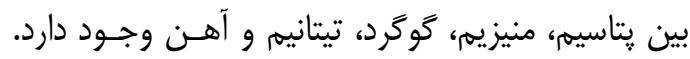

$$
\begin{aligned}
& \text { تفاصيل مذكور نشان از كشف اثر در بسترهاى مرتبط با بـا }
\end{aligned}
$$

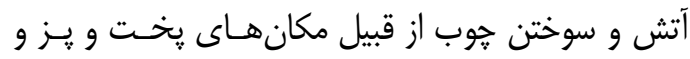

$$
\begin{aligned}
& \text { اجاق است. ويثزى هاى ساختارى و كانى شناختى نمونـهـ }
\end{aligned}
$$

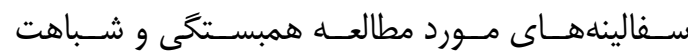

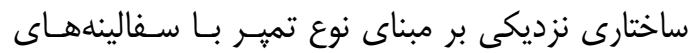

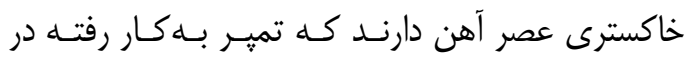

$$
\begin{aligned}
& \text { زمينهى رسى تمامى نمونههاى مـورد مطالعـه معـدنى، }
\end{aligned}
$$

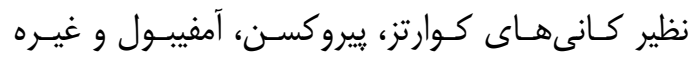

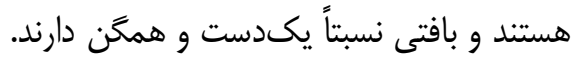

\section{يحىنوشتها}

1. Context

2. Lithogenic

3. Inductively coupled plasma-optical emission spectrometry

4. Ion chromatography

5. Polarized light microscopy

$$
\text { منابع فارسى }
$$

سلماسى، رامين. (ז9 (1). بررسى منشأ آلودَى آب به فلوئور در

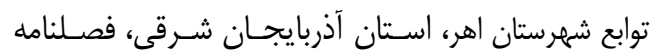
انسان و محيطزيست، شماره بأب.

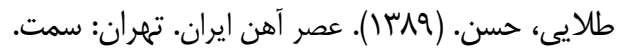

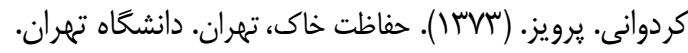

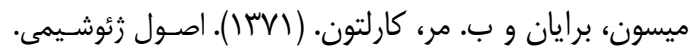
ترجمه فريد مر و على اصغر شرفى، شيراز: دانشگاه شيراز.

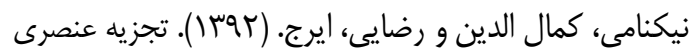

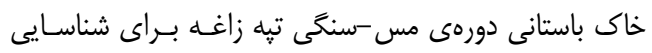

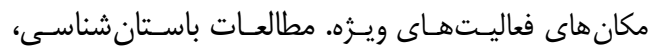

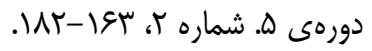

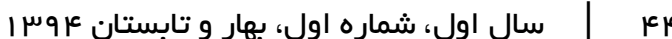


Roth, L. T. R. (2002). Total phosphorous use area determination of Lucayan settlements, middle Caicos, Turks and Caicos Islands, British West Indies. M.A. Thesis, Department of Archaeology, University of Calgary, Alberta.

Wells, E. C. (2004). Investigating activity patterns in prehispanic plazas, weak acid extraction,
ICP-AES analysis of anthrosols at Classic Period El Coyote, Northwestern Honduras. Archaeometry, (46), 67-84.

Woods, W. I. (1977). The quantitative analysis of soil phosphate. American Antiquity, (42), 248252.

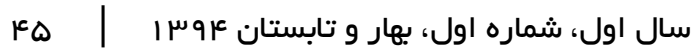

